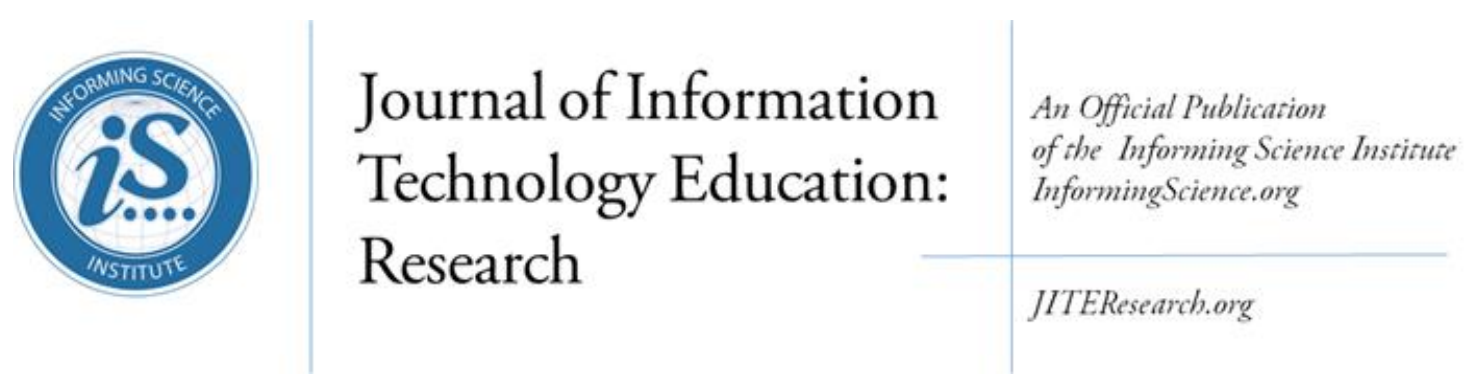

Volume 21, 2022

\title{
DESIGNING AND EVALUATING THE IMPACT OF USING A BLENDED ART COURSE AND WEB 2.0 TOOLS IN SAUDI ARABIA
}

Nouf Alsuwaida University of Ha'il, Ha’il, Saudi Arabia n.alsuwaida@uoh.edu.sa

\begin{abstract}
Aim/Purpose

This study designed and evaluated the impact of using a blended course and Web 2.0 tools into the "Design Fundamentals and Elements" course of a fine arts bachelor's program at a Saudi Arabian university. The study also examined how students used Web 2.0 tools to improve their learning in the design of a blended (hybrid) course following the Quality Matters TM Higher Education Rubric (QMHER).
\end{abstract}

Background

Web 2.0 tools such as Voki, YouTube, Pinterest, and Instagram feature educational technology that offers resources, helps instructors submit their lesson plans, create presentations, and conduct online student meetings.

Methodology

The research adopted a mixed-method approach: a qualitative and quantitative pilot study. Data were collected through a pre-survey, pre-test, and post-test for one focus group, and in-depth individual interviews.

Contribution

Blended courses should be integrated with the QMHER and Web 2.0 tools into art and design curricula. Art and design teaching and learning should be transformed through Web 2.0 tools, allowing students to explore their design capabilities in the fine arts, art education, interior design, fashion design, and graphic design fields.

Findings The findings revealed three themes in the data: 1) how to design blended learning best with the QMHER in an art education course, 2) Voki's impact on learning 21st-century skills in a blended course, and 3) Voki's impact on personal interactions from students' perspectives.

Recommendations The study suggests that blended courses featuring Voki animation activities play for Practitioners an important role in art education during the Covid-19 pandemic; students' favorite Web 2.0 tools can improve their learning, and Voki can offer a new method and animation tool that can be integrated into activities for art students.

Accepting Editor Donna Jean Satterlee | Received: November 19, 2021 | Revised: January 29, February 9, 2022 | Accepted: February 14, 2022.

Cite as: Alsuwaida, N. (2022). Designing and evaluating the impact of using a blended art course and Web 2.0 tools in Saudi Arabia. Journal of Information Technology Education: Research, 21, 25-52. https://doi.org/10.28945/4923

(CC BY-NC 4.0) This article is licensed to you under a Creative Commons Attribution-NonCommercial 4.0 International License. When you copy and redistribute this paper in full or in part, you need to provide proper attribution to it to ensure that others can later locate this work (and to ensure that others do not accuse you of plagiarism). You may (and we encourage you to) adapt, remix, transform, and build upon the material for any non-commercial purposes. This license does not permit you to use this material for commercial purposes. 
Recommendations for Researchers

Impact on Society

Future Research
Blended courses using Voki should be implemented as they can lead to improvements in students' 21 st-century skills (including technology literacy, creativity, decision-making, problem-solving, and collaboration and communication).

The QMHER was valuable for students' understanding of the course requirements and to improve their grades. Moreover, many Web 2.0 tools were helpful in teaching and learning art and design concepts. The findings highlight how students' 21st-century skills increased using Voki in a blended course.

The QMHER should be applied internationally to online and blended higher education courses.

Keywords blended course, Web 2.0, fine art

\section{INTRODUCTION}

The inclusion of technological advancements in education has influenced learning in the 21 st century. Web 2.0 has made teaching and learning available anywhere, at any time, in contrast to traditional classroom-based knowledge instruction. Moreover, the teaching and learning process is no longer primarily focused on the teacher and it is now undertaken in a more interactive and collaborative environment since practical communication skills are essential in the current era (Manty et al., 2017). This research aimed to improve teaching and learning in the art and design field by encouraging students to understand new technology tools and have fun during their courses. When an instructor creates a blended course for students, students can communicate and experience an online community. Art and design instructors in Saudi Arabia must develop curricula that help 21 st-century students compete with other students at the international level and achieve the country's 2030 Vision.

The present research aimed to improve the existing curricula in fine arts departments and inform updated pedagogical methods by incorporating recently developed educational technologies. Through newly designed and built blended course curricula, instructors will polish students' critical thinking and problem-solving skills. Thus, education will move forward, and information and communications technology (ICT) will be integrated into instruction, helping students become ICT-literate.

During the Covid-19 pandemic, Saudi Arabia's government decided to resume classes at all levels of education by using online and blended courses. Since then, the main gap has been that some art and design instructors have struggled to teach online or blended courses because they are unaccustomed to online education (Alghamdi, 2021). Moorhouse and Kohnke (2021) observed that the adaptations instructors made and the challenges they faced when adapting to the new mode of delivery in online courses helped them prepare for the suspension of on-campus classes caused by the Covid-19 pandemic or other health emergencies. Online learning has created challenges and opportunities for educators, educational technologists, and researchers of educational technologies and will likely continue to do so for a long time (Thompson \& Lodge, 2020). This need for research is extended to the local context, where there were no interventions in this field for using the QMHER when designing blended courses in arts education. The most challenging issue for lecturers is creating an effective plan for a blended course in art and design. The suggestion is to organize online or blended courses to understand the course process and avoid confusion or isolation. In the article, "Saudi University Students' Perceptions towards Virtual Education During Covid-19 Pandemic: A Case Study of Language Learning in Blackboard," Al-Nofaie (2020) explained the issues regarding students' readiness for this mode of education had been the main concerns in Saudi universities. One of the issues was that students were not accustomed to virtual classes before Covid-19. She suggests that universities should set out more practical lecturers and designers of professional development online or blended courses shortly. 
Thus, the purpose of this study was to apply the QMRHES in teaching art and design and set a plan and clear instructions in the "Design Fundamentals and Elements" course of the fine arts bachelor's program at a Saudi Arabian university. The study also evaluated how students used Web 2.0 tools to improve their learning. The researcher introduced a blended approach to solving the challenges students faced in an online course during the Covid-19 pandemic, attempting to improve 21st-century students' skills in art.

\section{RESEARCH QUESTION}

- How does the instructor design and evaluate a blended (hybrid) course intended to use Web 2.0 tools in the fine arts program?

\section{LITERATURE REVIEW}

\section{BLENDED LEARNING IN THE FLIPPED CLASSROOM}

Graham (2006) defined blended learning as a combination of instructional modalities or methods involving online and face-to-face $(\mathrm{F} 2 \mathrm{~F})$ instruction. Blended learning is an innovative approach that offers the advantages of traditional teaching while incorporating ICT-supported learning to improve the overall learning experience. The prime advantage of blended learning is that it gives rise to collaborative, computer-assisted, and constructive education (Lalima \& Dangwal, 2017) and allows students to receive immediate feedback on their efforts (Saliba et al., 2013).

The flipped classroom is a model of blended learning and teaching. O’Flaherty and Phillips (2015) highlighted that the flipped classroom improves the previous pedagogical models in higher education. In the flipped model, the instructor allows students to use technology, such as videos, before the class; after that, discussion and exercises form the link between the pre-class and F2F sessions. The flipped model enables teachers to cultivate critical and independent thought in their students, builds students' capacity for lifelong learning, and prepares future graduates for the workplace (Bishnoi, 2020). According to O'Flaherty and Phillips (2015), the "outcomes of implementing a successful flipped class approach should consider effective student learning that facilitates critical thinking, and importantly improves student engagement, both within and outside the class." (p. 95). Professors can provide video content for students by giving them access to high-quality videos from external sources or creating their own (Solomon \& Schrum, 2014). In this way, students can watch an explanation of a concept on their computers before class and become more responsible for their learning in the flipped environment.

Instructors can use the flipped model to climb Bloom's pyramid, a system used to classify the cognitive skills achieved and used in learning. This pyramid is also known as "Bloom's taxonomy," as it groups different skills and concepts in a similar way to the biological classification of organisms (Bieraugel \& Neill, 2017). Bloom's pyramid gets its name from Benjamin Bloom, an educational psychologist who developed cognitive skills that students need to learn. The pyramid/taxonomy comprises six levels of cognitive skills that build upon each other going up the pyramid, including knowledge, comprehension, application, analysis, synthesis, and evaluation (Burwash et al., 2016). Knowledge is located at the bottom of the pyramid and forms the foundation of all cognitive skills used in learning. Consequently, much time is dedicated to improving knowledge in school settings because it is the basis of cognition.

However, it is not sufficient to simply know facts and details; it is also important to understand them. This is the second pyramid level, which involves understanding the concepts taught in class. After understanding the concepts, students should apply them appropriately, which is the pyramid's third "application" level. The skills become more demanding as students approach higher levels of think- 
ing in the pyramid. At the analysis level, students should understand the different parts of information and interpret what they mean. In some cases, students may need to compare and contrast different concepts. Students must think beyond what they can see or read at the synthesis level, which calls for imagining situations that could arise given certain conditions (Zaidi et al., 2017). The highest level is evaluation, which involves developing and justifying personal opinions.

Blended learning makes use of both electronic and online media, as well as traditional learning approaches. In blended learning, Bloom's pyramid can be used in various ways. First, it can guide students' learning process, especially in the flipped classroom (Kaya, 2015). In the flipped classroom, students use digital media to learn the theoretical components of the course, then attend class to undertake practical activities under the teacher's supervision. According to Bloom's model, in the flipped classroom, digital media are used for lower model levels, that is, knowledge and comprehension. In contrast, the traditional classroom is suited for the application level and upward. Bloom's pyramid can also be used in the blended classroom to help improve students' cognitive skills at all levels of the pyramid (Andrade \& Coutinho, 2016). Helping instructors deliver their online promise means providing them with a collaborative and collegial process that focuses on continuous improvement. This process is designed to help instructors achieve their quality assurance goals for blended learning as they evolve to address all aspects of the Online Learning Quality Process (Figure 1).

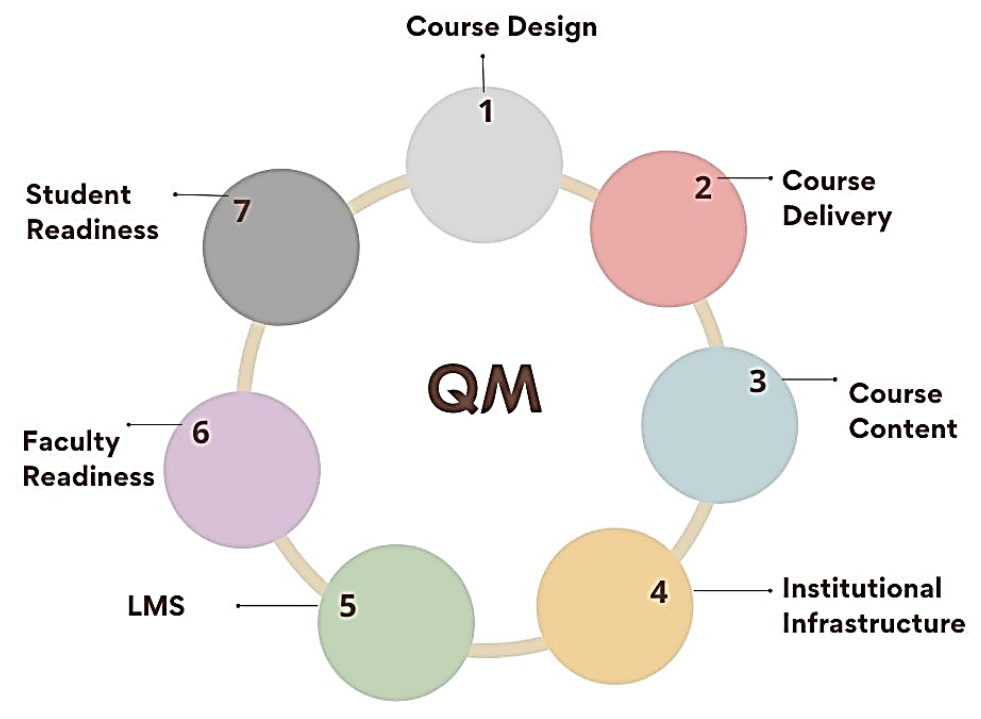

Figure 1: Online Learning Quality Process

\section{APPLYING THE QUALITY MATTERS ${ }^{T M}$ HIGHER EDUCATION RUBRIC}

The QMHER (6 $6^{\text {th }}$ edition) offers a model to help assure online and blended courses (Gregory et al., 2020). This rubric encompasses annotations explaining how the standards should be applied, alongside the relationship between the standards (Quality Matters, n.d.). It also provides a scoring system and online tools to facilitate the evaluation process. The QHEMR comprises eight general and 41 specific standards to evaluate the design of online and blended courses. The eight general standards of this rubric are described below.

\section{General Standard 1: Blended course overview, introduction, and policies}

This standard briefs students on what to expect and helps them succeed from the outset. The blended course policies suggest methods that enable all students to access the necessary learning materials to ensure quality outcomes. The policy concerns should cover the pedagogy and technology 
issues that underlie the program's implementation. The policy should cover the evaluation of the delivery advantage to students in terms of their geographical location, finances, learning style, and familiarity with the technology (Wallace \& Young, 2010).

\section{General Standard 2: Measurable learning objectives or competencies}

The second standard establishes a foundation upon which the rest of the course is based. Bloom's taxonomy provides a set of measurable and realistic learning objectives for blended courses, outlining six important categories for course design that encompass the setting of objectives, class activities, and the evaluation process. The six categories include the basis for imparting knowledge, comprehension, application, analysis, synthesis, and course evaluation. Specifically, it informs students what they should study and how they will be assessed, guides the instructor on the teaching and assessment strategies, and informs the instructor whether the teaching and assessment strategies applied were effective (Wallace \& Young, 2010).

\section{General Standard 3: Assessment and measurement}

According to Minnesota State University Moorhead (2017), blended learning should entail multiple assessment and feedback opportunities to help gauge students' learning progression and opportunities for re-learning. The assessment measurement should facilitate learning that fosters mastery of the learning objectives. The assessment techniques that could aid this process include formative, summative, and fixed-choice assessments.

\section{General Standard 4: Instructional material}

Once the course objectives and assessment criteria have been defined, the instructor should work on the learning materials and tools. These are the resources that will aid the students in working through the set assessments to meet the course objectives. Some choices to be made may include whether the instructor should write or record the materials or opt to incorporate other people's work, such as articles, texts, or videos (Quality Matters, n.d.).

\section{General Standard 5: Activities and learner interaction}

The outcome of any program depends largely on student engagement. Therefore, the instructor must work on the engagement criteria to improve students' motivation to meet the learning challenges. The program must create an effective forum for interaction with the content, fellow students, and the instructor (Futch et al., 2016).

\section{General Standard 6: Course technology (tools)}

The technologies enabling the various tools used in the course should facilitate the learning process (Minnesota State University Moorhead, 2017). The tools used in the course should support the learning objectives and promote learner engagement through activities (Quality Matters, n.d.).

\section{General Standard 7: Learner support}

It is important to ensure that online learners know they have access to various support services. Four different kinds of support services are addressed: technical support, accessibility support, academic services support, and student services support (Quality Matters, n.d.).

\section{General Standard 8: Accessibility and usability}

The course design should reflect a commitment to accessibility (ensuring all students can access all course content and activities) and usability (ensuring all learners can easily navigate and interact with the course components; Rice \& Oritz, 2020). Figure 2 shows the QMHER (6 $6^{\text {th }}$ edition). 


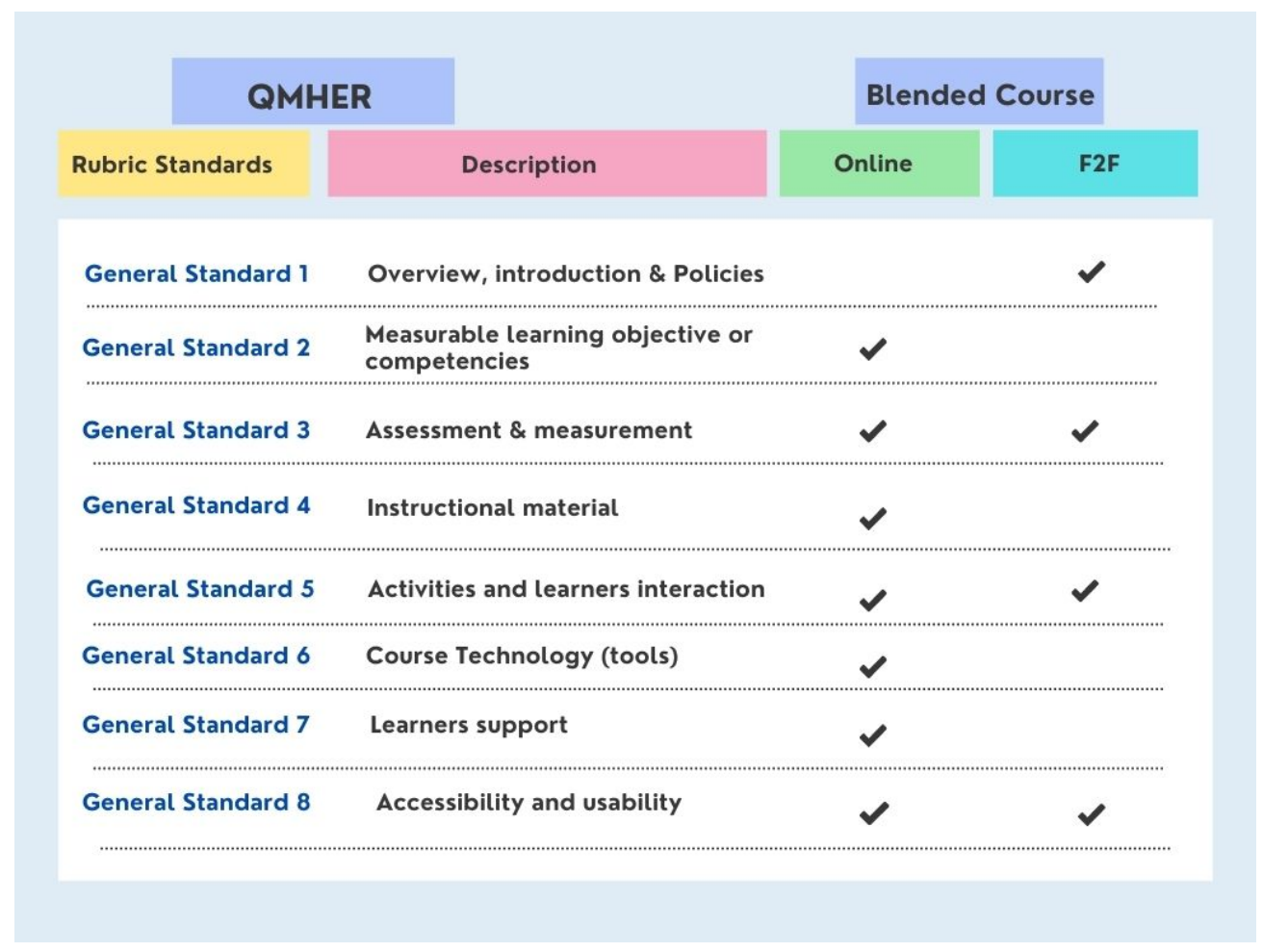

Figure 2: The Quality Matters TM Higher Education Rubric

\section{WEB 2.0 TECHNOLOGY TOOLS IN HIGHER EDUCATION}

Web 2.0 tools are digital tools that enable access to, and the production of, knowledge. Solomon and Schrum (2014) defined Web 2.0 as "a second generation of the World Wide Web that focuses on the ability for people to collaborate and share information online." (p. 2). Online learning has changed the education sector globally, and instructors must use technology tools in instructional design by matching the most appropriate digital tools to their pedagogy (Manning \& Johnson, 2011). Keengwe and Agamba (2015) emphasized that Web 2.0 tools support active learning and facilitate sharing and communication between students and their peers and between students and instructors. Students can build their learning network to improve their learning and gain more experience.

Social media is a group of tools, including websites and applications, enabling users to create and share content or participate in social networking. Social media incorporates the arts of learning, listening, and sharing information. Social media provides effective tools for people who want to meet others with similar interests and ideas. Several popular social networking communities are used in higher education and marketing (Reuben, 2008); for example, educators may use some of the most popular social media websites in their teaching, such as Twitter, Instagram, LinkedIn, Tumblr, Google blogs, Pinterest, Snapchat, YouTube, and Facebook.

"Visual learning" refers to the assimilation of information from visual cues. Students understand information better in the classroom when they can see it (Rodger et al., 2009). Different visual resources can be used during classes, such as images, flowcharts, diagrams, videos, simulations, graphs, cartoons, coloring books, posters, films, games, and flashcards (Rodger et al., 2009). Visual learning is an effective strategy for teaching and learning art and design. Art and design students learn more by seeing and doing in the classroom as visual learners (Riley, 2017). Raiyn (2016) introduced new concepts to students using visual learning tools such as images, diagrams, flowcharts, and interactive simulations; the results showed that visual learning tools increased students' higher-order thinking skills. Animation is one type of visual learning or Web 2.0 tool; through animation tools, students can enjoy 
creating their animations or images to present in the classroom (Solomon \& Schrum, 2014). Voki is another Web 2.0 tool or animation technology tool for art and design students. Computer animation constitutes a creative teaching and learning method in the classroom. Teachers can use animation to capture students' attention and make learning more attractive, and many animation applications offer new teaching and learning approaches in higher education. Mayer and Moreno (2002) defined animation as a form of pictorial presentation that comprises computer-generated motion pictures showing associations between drawn elements, such as pictures, videos, and illustrations, to depict the movement of real objects. The advent of computers has helped both teachers and students develop disciplines and training (Xiao, 2013). A significant improvement has been observed in students' attitudes and academic achievements when using animation in education (Baglama et al., 2018).

Educators at different levels have noted that computer animation can be critical in enhancing students' creativity and innovation in the classroom (Beatty et al., 2020). Educational animations can be displayed through a projector in the classroom (Jintapitak, 2018). Animated films can also be used in a classroom environment. Most students enjoy images and films; therefore, they can encourage students to be more attracted to the topic of study (Paik \& Schraw, 2013). There are several reasons why professors use animations in the classroom (instead of traditional teaching materials). Among them is that students find animations more interesting than traditional teaching approaches. This makes the professor and the students active, yielding better learning outcomes (Hamdan, 2019).

Moreover, animations can help create a shared viewing experience that fosters collaborative efforts in the classroom as learners develop teamwork skills, leading to learning outcomes (Frick, 1991). Further, animations can convey information efficiently to learners; similar to films, songs, and other forms of media, instruction using animations can encourage learners to pay attention to the learning topic. Some companies have developed individual production platforms for animation in education. One example is Voki, a Web 2.0 tool that allows students to create an animated character with an audio track. Voki offers vodcasts and voice-recordings that can help evaluate, analyze, and create thinking skills and improve peer collaboration (Cicconi, 2014). Yeşilbağ and Korkmaz (2021) used Voki in an English course and observed students' test scores. Consequently, the authors recommended that English instructors use the Voki application in speaking activities in class. Moreover, Voki can help students clarify their views and engage them in the classroom. Thus, this technology could be important for arts activities, and designing animated characters can benefit teachers and students through increased class engagement (Cunningham, 2013).

Based on the literature reviewed, this study focused on the different ways that students can use Web 2.0 tools to improve their learning using Voki as a new application in a blended (hybrid) course following the QMHER. Voki and other Web 2.0 tools provide instructors with teaching resources, helps them submit their lesson plans and create presentations, and allows online communication and creativity. Thus, this type of course effectively develops and prepares students' 21 st-century skills by blending F2F learning and technology in the arts environment. Although several studies have discussed using blended courses featuring Voki to improve speaking skills in English courses, they have failed to apply the QMHER when using Voki in class. Additionally, no studies in Saudi Arabia have used Voki or the QMHER when designing courses in arts education or other subjects. As such, this study offers critical guidance for instructors when creating blended courses on any topic with the QMHER. Simultaneously, it aims to help educators understand learners' needs to assist them in their educational journey.

\section{MATERIALS AND METHODS}

\section{RESEARCH DESIGN}

This study adopted a pilot study to produce an in-depth description of one small group with a specific duration and location. Before experimenting, the researcher submitted a research proposal to the ethics committee of the target institution, a university in Saudi Arabia. This proposal was approved, 
and the research was conducted in the Fall 2020 semester, from August 30 to December 30, on the main campus for female students. The research was undertaken in the Department of fine arts at the university. The researcher selected learners taking the "Design Fundamentals and Elements" course, which is offered to undergraduate students. The case study examined the outcomes of using Web 2.0 as technological tools that could upgrade art and design teaching and learning in a blended (hybrid) course by using QHEMR. Data were collected from various sources, including a pre-survey, pre-test and post-test for one focus group and in-depth individual interviews.

\section{PARTICIPANT DEMOGRAPHICS}

In fall 2020, 25 female undergraduate students enrolled in the traditional course, but only 14 female undergraduate students agreed to participate in the blended course. A pre-survey collected demographic data, including participants' gender, age, nationality, language, level of undergraduate education, English language skills, computer skills, email address, and cellphone numbers. All participants were female, between 18 and 24, of Saudi nationality, and stated that Arabic was their native language. The participants were at different levels of undergraduate education: $92.8 \%$ were seniors, and $7.14 \%$ were juniors. Moreover, the participants demonstrated different proficiency levels in the English language: $35.71 \%$ had basic skills, $57.14 \%$ were at the intermediate level, and $7.14 \%$ were at an advanced level. Finally, the participants demonstrated in Table 1 varying levels of computer literacy: $14.28 \%, 71.42 \%$, and $14.28 \%$ had basic, intermediate, and advanced skills, respectively.

Table 1: Demographic of art education students

\begin{tabular}{|c|c|c|c|}
\hline Variable & Class & Number & Percentage \\
\hline Gender & Female & 14 & $100 \%$ \\
\hline Age & $18-24$ years old & 14 & $100 \%$ \\
\hline Nationality & Saudi & 14 & $100 \%$ \\
\hline Native language & Arabic & 14 & $100 \%$ \\
\hline Level of Education & Juniors & 1 & $7.14 \%$ \\
& Seniors & 13 & $92.8 \%$ \\
\hline English language skills & Basic & 5 & $35.71 \%$ \\
& Intermediate & 8 & $57.14 \%$ \\
& Advanced & 1 & $7.14 \%$ \\
\hline Computer skills & Basic & 2 & $14.28 \%$ \\
& Intermediate & 9 & $71.42 \%$ \\
& Advanced & 2 & $14.28 \%$ \\
\hline
\end{tabular}

\section{DATA COLLECTION TOOLS AND PROCESS}

The study's data were obtained by implementing a pre-survey, pre-test and post-test, one focus group, and in-depth individual interviews. The pre-survey collected demographics to allow the researcher to understand the participants before the study began. Pre-test and post-test focus groups are another research method for collecting participants' information using a questionnaire. The pre-test focus group of 14 students was asked questions before the semester began and before Web 2.0 tools were introduced in the blended course. After that, the post-test focus group of the same students was asked the same questions at the end of the blended course. The pre-test and post-test focus groups answered the same questions about using blended learning and Web 2.0 tools, such as Voki, 
YouTube, Pinterest, Instagram, and WhatsApp in the classroom. The pre-test and post-test questions included two sections which were:

First: Blended course

1. Blended course increases the effectiveness of the role of the student during the learning process and makes her play a primary role in this process, not secondary.

2. Blended course gives clear instructions on what students should do in both online and F2F.

3. Blended course develops the students' skills of self-learning and continuous learning and the search for knowledge.

4. Blended Course with web 2.0 improves the skills of learning the English language due to the presence of technical tools and various sites that support this language.

5. Blended Course with web 2.0 develops computer skills, the use of the Internet, e-mail and various social media.

6. Blended course with web 2.0 gives the learner freedom and daring to express himself in online assignments.

7. Blended course helps to integrate with the online world as a whole and to learn new things in art and design.

8. Blended course fills the shortage of equipment and laboratories in art.

9. Blended course enables creativity in the product during the learning art process.

10. Blended course provides opportunities for different types of interaction (visual, verbal, and written).

Second: Web 2.0 tools

1. Web 2.0 tools entertain and motivate students between each other by using various techniques, technology tools in art.

2. Web 2.0 tools facilitate learners' participation in art courses anywhere.

3. Web 2.0 tools increase students' visual nurturing and inspiration while designing.

4. Web 2.0 tools encourages cooperation between learners.

5. Web 2.0 tools reduce the costs of purchasing materials and technical tools, and instead uses applications and technical tool programs in drawing and designing.

6. Web 2.0 tools allow students to restrict access to their work.

7. Web 2.0 tools allow students to retain sole Intellectual Property rights to the content their create.

8. Web 2.0 tools are easy to use and make it easy to track student work.

More in-depth, semi-structured interviews were then conducted with seven students selected from the entire sample of 14. The individual interviews contained open-ended questions and lasted 30 minutes for each participant. The purpose of these interviews was to allow the participants to describe their reflections on and experiences using Web 2.0 and a blended method at the end of the course.

\section{DATA ANALYSIS PROCEDURE}

Both the focus groups and in-depth interviews were audio-recorded. SPSS software was used for data analysis. The interviews were first transcribed into Arabic, the students' native language; thereafter, the transcripts were translated into English, along with the field notes. The Question was filled on a five point Likert scale with strongly agree rated as 5 , agree with 4 , somewhat agree with 3 , disagree with 2 and strongly disagree with 1 . The scores for the participants in each group were then summed together and a paired t test performed. 


\section{RESULTS}

\section{THEME 1: DESIGNING A BLENDED LEARNING COURSE WITH THE QMHER IN AN ART EDUCATION PROGRAM}

In this study, the QMHER (6 $6^{\text {th }}$ edition) offers a model to help researchers assure blended course quality design. The three-credit blended course "Design Fundamentals and Elements" began in the fall of 2020 and included 50\% on-campus/F2F instruction and 50\% online instruction using the Blackboard LMS and other Web 2.0 tools, including Voki Classroom 2.0, Pinterest, and YouTube. F2F meetings were held twice per month for two hours at a time. In each F2F meeting, meeting times, class activities, learning objectives or competencies, and outcomes were discussed. The modules contained instruction, materials, and work or assignments that students had to submit online before the F2F meetings. Students completed various activities in class, such as drawing and painting with drawing materials and tools. The course was a flipped type that followed the QMHER.

An online Voki Classroom was introduced to the course. This technology is efficient and allows instructors easy access to use, create, and assign activities. Voki Classroom is designed to help instructors manage students' work. Teachers can use this tool to assign students classwork and homework and review their submissions in real-time, either from a desktop or mobile device, offering a convenient way to assess their knowledge. Instructors provide students with login access; therefore, students are not required to register or provide personal information. Voki offers three levels of plans; the researcher selected Level 1 as appropriate for the sample class of 30 students, which allowed access to Voki Classroom, Voki Creator, Voki Presenter, and Voki Hangouts. The researcher created a new online class with a Voki account to assist with the class activities and use Blackboard. Students enrolled in the online class by adding their names and email addresses and were then provided with their usernames and passwords to login to the course. The researcher assigned Voki, YouTube, Instagram, Pinterest, and WhatsApp as assignments in the blended course. The following Table 2 shows how researcher set the schedule of teaching modules with different subjects during the blended course:

Table 2: Timeline of the blended course modules

\begin{tabular}{|l|c|l|}
\hline Modules & Period & \multicolumn{1}{|c|}{ Subjects } \\
\hline Module 1 & Sep 2020 & $\begin{array}{l}\text { Introduction and definition of } \\
\text { design }\end{array}$ \\
\hline Module 2 & Oct 2020 & The elements of design \\
\hline Module 3 & Nov 2020 & The principles of design \\
\hline Module 4 & Dec 2020 & Evaluation and Final Exams \\
\hline
\end{tabular}

\section{Course description}

The course aimed to study nature as a source of design and creation and teach the elements and fundamentals of design, offering training and skills development in the use of materials, tools, and methods for application in various designs. The course provided students with information on the elements and basis of design in preparation for studying functional form and nature and, ultimately, learning the aesthetics of shape and the foundations of its creation. It also offered training and skills development in using textures in design. All activities listed on the schedule and checklist were mandatory for students and were uploaded to Blackboard. Items that required a submission were indicated in the schedule. 


\section{Blended course modules}

The course was organized into modules. Alignment throughout such modules involves objectives or competencies and assessments and instructional materials, learning activities, and course tools. All these components must work together to support learners' achievement of the objectives or competencies, as demonstrated by successful course assessments. Moreover, General Standard 7 of the QMHER states that learner access to institutional support services is essential to success. At the same time, General Standard 8 stipulates that the course design should reflect a commitment to accessibility and usability for all higher education students. The following demonstrates how the four modules in this blended course were organized with General Standard 1, 2, 3, 4, 5, and 6 of the QMHER (Tables 3, 4, 5, and 6).

Table 3: Module 1: Getting started: Introduction and definition of design

\begin{tabular}{|l|l|}
\hline General Standard 1: & $\begin{array}{l}\text { The module included an orientation, a wel- } \\
\text { come message from the instructor, the sylla- } \\
\text { bus, the grading policy and office hours, the } \\
\text { schedule of F2F meetings, and an opportunity } \\
\text { for students to introduce themselves. }\end{array}$ \\
\hline $\begin{array}{l}\text { General Standard 2: } \\
\text { Objectives or competencies }\end{array}$ & $\begin{array}{l}\text { The objectives were organized into two levels: } \\
\text { 1-course-level objectives. } \\
\text { 2-module-level objectives. } \\
\text { The course-level objective was "upon comple- } \\
\text { tion of this course, students will be able to un- } \\
\text { derstand the definition of design, its im- } \\
\text { portance, design materials, and types of de- } \\
\text { sign." } \\
\text { The module-level objectives were as follows: } \\
\text { 1) Students will define design and art. } \\
\text { 2) Students will describe the importance and } \\
\text { aims of art and design. } \\
\text { 3) Students will identify different materials and } \\
\text { tools used in constructing design forms. } \\
\text { 4) Students will identify different materials and } \\
\text { tools used in constructing design forms. } \\
\text { 5) Students will create a sketch for one type of } \\
\text { design. }\end{array}$ \\
\hline General Standard 3: & $\begin{array}{l}\text { The course used both online and F2F teaching } \\
\text { methods. The instructor set a pre-quiz in Black- } \\
\text { board, and an assignment in Voki Create in the } \\
\text { online instruction. Meanwhile, the F2F was a } \\
\text { group drawing workshop with a checklist. }\end{array}$ \\
\hline
\end{tabular}




\begin{tabular}{|l|l|}
\hline General Standard 4: & $\begin{array}{l}\text { During online instruction, the instructor used } \\
\text { the LMS (Blackboard), online lectures (Ultra or } \\
\text { Conference in Blackboard), audio and/or video } \\
\text { content (YouTube), Web 2.0 and social media } \\
\text { tools (e.g., WhatsApp, Pinterest, and YouTube), } \\
\text { and websites (such as the Voki Create tool). } \\
\text { The F2F instruction employed textbooks, study } \\
\text { guides, mini-lectures, PowerPoint presentations, } \\
\text { and case studies. }\end{array}$ \\
\hline General Standard 5: & $\begin{array}{l}\text { Students read Chapter 1 from the textbook Ele- } \\
\text { ments and principles of design. A great tool to learn about } \\
\text { design: Designing principle guide (Wamboldt, 2021), and } \\
\text { watched YouTube videos. }\end{array}$ \\
\hline General Standard 6: & $\begin{array}{l}\text { The instructor used the LMS (Blackboard), the } \\
\text { Voki Online Classroom Create tool, YouTube } \\
\text { Tideos, WhatsApp, Pinterest, and drawing kit } \\
\text { tools. }\end{array}$ \\
\hline
\end{tabular}

Table 4: Module 2: The elements of design

\begin{tabular}{|l|l|}
\hline General Standard 1: & $\begin{array}{l}\text { The introduction included the study of designs } \\
\text { elements and training in point, line, shape, size, } \\
\text { texture, value, color, space, and form. }\end{array}$ \\
\hline General Standard 2: & $\begin{array}{l}\text { The objectives were categorized at the course } \\
\text { and module levels. } \\
\text { The course-level objective was "upon comple- } \\
\text { tion of this course, students will be able to ap- } \\
\text { ply the elements of design and the training } \\
\text { guidelines." } \\
\text { The module-level objectives were: }\end{array}$ \\
& $\begin{array}{l}\text { 1) Students will define the elements of design. } \\
\text { 2) Students will describe and produce the ele- } \\
\text { ments of design. }\end{array}$ \\
& $\begin{array}{l}\text { 3) Students will identify different elements of } \\
\text { design. }\end{array}$ \\
& $\begin{array}{l}\text { 4) Students will draw each element of design } \\
\text { (point, line, shape, size, texture, light, and shad- } \\
\text { ows, color). }\end{array}$ \\
\hline General Standard 3: & $\begin{array}{l}\text { The online activities included a discussion } \\
\text { board (Voki Hangouts) and Quiz 1 in Black- } \\
\text { Board. The F2F activities included mini-lec- } \\
\text { tures, F2F tutorials, workshop sessions (using } \\
\text { Sketch and color art kit tools), and a group } \\
\text { Arawing workshop with a checklist. }\end{array}$ \\
\hline
\end{tabular}




\begin{tabular}{|l|l|}
\hline $\begin{array}{l}\text { General Standard 4: } \\
\text { Instructional material }\end{array}$ & $\begin{array}{l}\text { The online activities included a discussion } \\
\text { board (Voki Hangouts) and Quiz 1 in Black- } \\
\text { board. The F2F activities included mini-lec- } \\
\text { tures, F2F tutorials, workshop sessions (using } \\
\text { Sketch and color art kit tools), and a group } \\
\text { drawing workshop with a checklist. }\end{array}$ \\
\hline $\begin{array}{l}\text { General Standard 5: } \\
\text { Activities and learner interaction }\end{array}$ & $\begin{array}{l}\text { Students read Chapter 2 from the textbook Ele- } \\
\text { ments and principles of design. A great tool to learn about } \\
\text { design: Designing principle guide (Wamboldt, 2021), } \\
\text { watched YouTube videos, and discussed the } \\
\text { content in groups both online and on campus. }\end{array}$ \\
\hline General Standard 6: Tools & $\begin{array}{l}\text { These included the LMS (Blackboard), the Voki } \\
\text { online classroom (Hangouts tool), YouTube } \\
\text { videos, Instagram, Pinterest, and drawing kit } \\
\text { tools. }\end{array}$ \\
\hline
\end{tabular}

Table 5: Module 3: The principles of design

\begin{tabular}{|l|l|}
\hline $\begin{array}{l}\text { General Standard 1: } \\
\text { Overview and introduction }\end{array}$ & $\begin{array}{l}\text { The introduction covered the principles of de- } \\
\text { sign, including unity, rhythm, balance, pattern, } \\
\text { contrast, emphasis, scale, harmony, and variety. }\end{array}$ \\
\hline $\begin{array}{l}\text { General Standard 2: Objectives or } \\
\text { competencies }\end{array}$ & $\begin{array}{l}\text { The objectives were categorized into course- } \\
\text { and module-level objectives. The course-level } \\
\text { objective was "upon completion of this course, } \\
\text { students will be able to apply the principles of } \\
\text { design and the training guidelines." There were } \\
\text { four module-level objectives, including the fol- } \\
\text { lowing: } \\
\text { 1) Students will define the principles of design. } \\
\text { 2) students will describe and produce the prin- } \\
\text { ciples of design. } \\
\text { 3) Students will identify different principles of } \\
\text { design. } \\
\text { 4) Students will draw each principle of design. }\end{array}$ \\
\hline $\begin{array}{l}\text { General Standard 3: Assessment } \\
\text { and measurement }\end{array}$ & $\begin{array}{l}\text { The online assessments included a presentation } \\
\text { in Voki Present and Quiz 2 in Blackboard. The } \\
\text { F2F assessments included mini-lectures, F2F } \\
\text { tutorials, workshop session tools (Sketch and } \\
\text { color art kit tools), and a group drawing work- } \\
\text { shop with a checklist. }\end{array}$ \\
\hline
\end{tabular}




\begin{tabular}{|l|l|}
\hline $\begin{array}{l}\text { General Standard 4: Instructional } \\
\text { material }\end{array}$ & $\begin{array}{l}\text { The online instructional materials included the } \\
\text { LMS (Blackboard), online lectures (Ultra or } \\
\text { Conference in Blackboard), audio and/or video } \\
\text { content (YouTube), Web 2.0 tools, social media } \\
\text { (WhatsApp, Pinterest, YouTube), and the Voki } \\
\text { Present tool. The F2F instructional materials } \\
\text { included textbooks, study guides, mini-lectures, } \\
\text { presentations, PowerPoints, and case studies. }\end{array}$ \\
\hline $\begin{array}{l}\text { General Standard 5: Activities and } \\
\text { learner interaction }\end{array}$ & $\begin{array}{l}\text { In this module, students read Chapter 3 from } \\
\text { the textbook Elements and principles of design. A great } \\
\text { tool to learn about design: Designing principle guide (Wam- } \\
\text { boldt, 2021), watched YouTube videos, submit- } \\
\text { ted presentations, and participated in F2F } \\
\text { groups. }\end{array}$ \\
\hline General Standard 6: Tools & $\begin{array}{l}\text { These included the LMS (Blackboard), the Voki } \\
\text { Online Classroom Present tool, YouTube vid- } \\
\text { eos, WhatsApp, Instagram, Pinterest, and draw- } \\
\text { ing kit tools. }\end{array}$ \\
\hline
\end{tabular}

Table 6: Module 4: Evaluation and Final Exams

\begin{tabular}{|l|l|}
\hline $\begin{array}{l}\text { General Standard 1: Overview and } \\
\text { introduction }\end{array}$ & $\begin{array}{l}\text { The module trained students to establish the } \\
\text { foundations of the elements and principles of } \\
\text { design. }\end{array}$ \\
\hline $\begin{array}{l}\text { General Standard 2: Objectives or } \\
\text { competencies }\end{array}$ & $\begin{array}{l}\text { The objectives were categorized into course- } \\
\text { and module-level objectives. The course-level } \\
\text { objective was "upon completion of this course, } \\
\text { students will be able to evaluate each other's } \\
\text { artwork and research on the elements and prin- } \\
\text { ciples of design." There were four module-level } \\
\text { objectives: }\end{array}$ \\
$\begin{array}{l}\text { 1) Students will choose one element or princi- } \\
\text { ple of design. } \\
\text { 2) Students will research one element or princi- } \\
\text { ple of design. } \\
\text { 3) Students will give a presentation on one ele- } \\
\text { ment or principle of design. }\end{array}$ \\
$\begin{array}{l}\text { 4) Students will evaluate the artworks created by } \\
\text { their peers. }\end{array}$ \\
\hline $\begin{array}{l}\text { General Standard 3: Assessment } \\
\text { and measurement }\end{array}$ & $\begin{array}{l}\text { This module employed only online assessment } \\
\text { methods, including a research paper, final writ- } \\
\text { ten exam, final presentation, and final project. }\end{array}$ \\
\hline material Standard 4: Instructional & $\begin{array}{l}\text { These included the final written exam, final } \\
\text { presentation, and final project. }\end{array}$ \\
\hline
\end{tabular}




\begin{tabular}{|l|l|}
\hline $\begin{array}{l}\text { General Standard 5: Activities and } \\
\text { learner interaction }\end{array}$ & $\begin{array}{l}\text { Students read all chapters of the textbook, re- } \\
\text { viewed all posted YouTube videos, and com- } \\
\text { pleted the digital portfolio file. }\end{array}$ \\
\hline General Standard 6: Tools & $\begin{array}{l}\text { These comprised the LMS (Blackboard), re- } \\
\text { search paper, Voki Online Classroom Present } \\
\text { tool, and Voki slides. }\end{array}$ \\
\hline
\end{tabular}

\section{THEME 2: STUDENTS' EVALUATION OF THE BLENDED COURSE USING WEB 2.0}

After designing the blended course, the researcher gave students pre-test (questionnaire) to one focus group before the beginning of the course. Then, after students participated the blended course by using Web 2.0 tools, the researcher gave the students post-test (questionnaire) to evaluate the students experience of a blended course and Web 2.0 tools

Table 7: Web 2.0 and blended course normality test

Tests of Normality

\begin{tabular}{lr|r|r|r|r|r} 
& \multicolumn{3}{c|}{ Kolmogorov-Smirnov } & \multicolumn{3}{c}{ Shapiro-Wilk } \\
& Statistic & df & \multicolumn{1}{c}{ Sig. } & Statistic & df & \multicolumn{1}{c}{ Sig. } \\
\hline Web 2.0 tools (pre) & .183 & 8 & $.200^{n}$ & .952 & 8 & .728 \\
\hline Web 2.0 tools (post) & .226 & 8 & $.200^{n}$ & .942 & 8 & .631 \\
\hline $\begin{array}{l}\text { First : Blended course: } \\
\text { (pre) }\end{array}$ & .286 & 8 & .053 & .779 & 8 & .017 \\
\hline $\begin{array}{l}\text { First :Blended course: } \\
\text { (post) }\end{array}$ & .234 & 8 & $.200^{n}$ & .954 & 8 & .754 \\
\hline
\end{tabular}

*. This is a lower bound of the true significance.

a. Lilliefors Significance Correction

Table 8: Web 2.0 and blended course descriptive statistics

Paired Samples Statistics

\begin{tabular}{llc|r|r|r} 
& Mean & N & Std. Deviation & \multicolumn{1}{c}{$\begin{array}{c}\text { Std. Error } \\
\text { Mean }\end{array}$} \\
\hline Pair 1 & Web 2.0 tools (post) & 66.3750 & 8 & 2.44584 & .86474 \\
\cline { 2 - 6 } & Web 2.0 tools (pre) & 56.8750 & 8 & 2.35660 & .83318 \\
\hline Pair 2 & $\begin{array}{l}\text { First :Blended course: } \\
\text { (post) }\end{array}$ & 68.2000 & 10 & 2.14994 & .67987 \\
\cline { 2 - 6 } & $\begin{array}{l}\text { First :Blended course: } \\
\text { (pre) }\end{array}$ & 52.0000 & 10 & 3.39935 & 1.07497 \\
\hline
\end{tabular}


Before running the paired $t$ test, assumptions of $t$ test were tested. The assumption that the observations be dependent were valid as the same participants were tested before and after the intervention. In addition, the assumption that the differences between pre and post scores be normally distributed were valid for both Web 2.0 and first blended course as evidenced by both the histograms (Figures 3 and 4) and Shapiro Wilk test $(p>.05)$ (Table 7). Finally, the assumption that there be no influential outliers in the differences between the scores was also valid as indicated by boxplots of both Web 2.0 and first blended course (Figures 5 and 6 ). With all the assumptions being valid the dependent $t$ test was performed using SPSS statistical package.

The mean for web 2.0 pretest was found to be 56.88 with a standard deviation of 2.36 while the mean for web 2.0 posttest was found to be 66.38 with a standard deviation of 2.45 (Table 8). On the other hand, the mean for pretest for first blended course was found to be 52.0 with a standard deviation of 3.40 while for posttest was 68.2 with a standard deviation of 2.15 . With a $t(7)=7.58$, $p=$ $<.0001$ (Table 9). This was an indication that web 2.0 test was statistically significant. Likewise, with a $t(7)=7.58, p=<.0001$ the test for blended course was statistically significant. As such, the null hypothesis were rejected for both hypothesis. Therefore, there was sufficient evidence to conclude that there was a positive impact of using blended course and Web 2.0 tools into the course of an art education bachelor's program at a Saudi Arabian university in the Fall 2020.

Table 9: Web 2.0 tools and blended course paired $t$ test output

\begin{tabular}{|c|c|c|c|c|c|c|c|c|c|}
\hline \multicolumn{10}{|c|}{ Paired Samples Test } \\
\hline & & \multirow[b]{3}{*}{ Mean } & \multicolumn{4}{|c|}{ Paired Differences } & \multirow[b]{3}{*}{$t$} & \multirow[b]{3}{*}{ df } & \multirow[b]{3}{*}{ Sig. (2-tailed } \\
\hline & & & \multirow[b]{2}{*}{ Std. Deviation } & \multirow{2}{*}{$\begin{array}{l}\text { Std. Error } \\
\text { Mean }\end{array}$} & \multicolumn{2}{|c|}{$\begin{array}{l}\text { 95\% Confidence Interval of the } \\
\text { Difference }\end{array}$} & & & \\
\hline & & & & & Lower & Upper & & & \\
\hline Pair 1 & $\begin{array}{l}\text { Web } 2.0 \text { tools (post) - } \\
\text { Web } 2.0 \text { tools (pre) }\end{array}$ & 9.50000 & 3.54562 & 1.25357 & 6.53579 & 12.46421 & 7.578 & 7 & .000 \\
\hline Pair 2 & $\begin{array}{l}\text { First:Blended course: } \\
\text { (post) - First :Blended } \\
\text { course:(pre) }\end{array}$ & 16.20000 & 3.42540 & 1.08321 & 13.74962 & 18.65038 & 14.956 & 9 & .000 \\
\hline
\end{tabular}

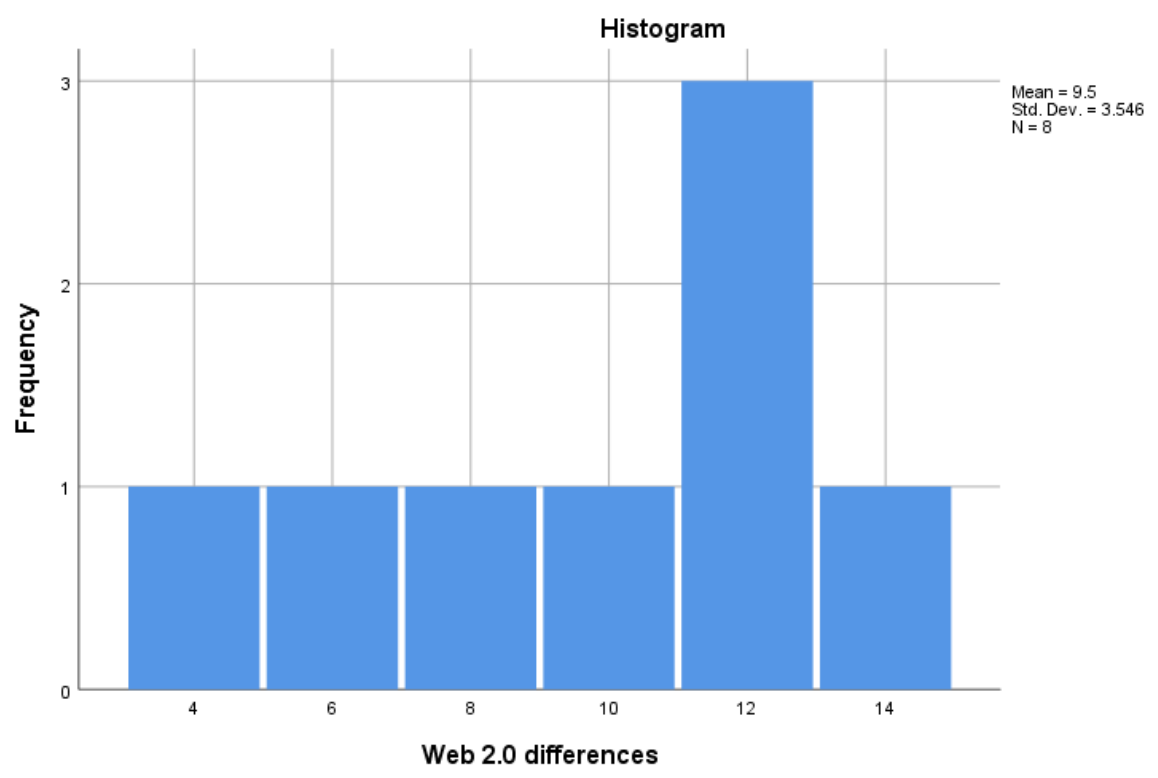

Figure 3: Differences in pre and post web 2.0 tools histogram 


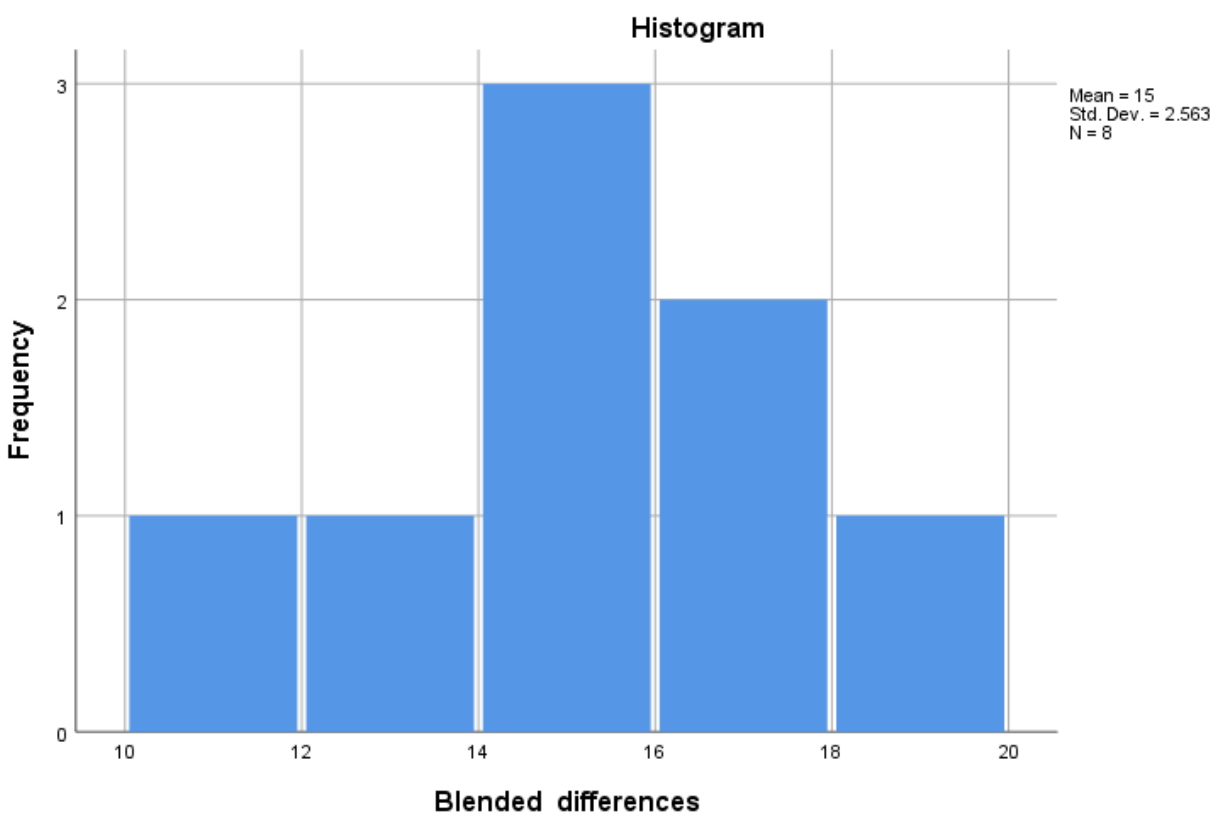

Figure 4: Differences in pre and post blended differences histogram

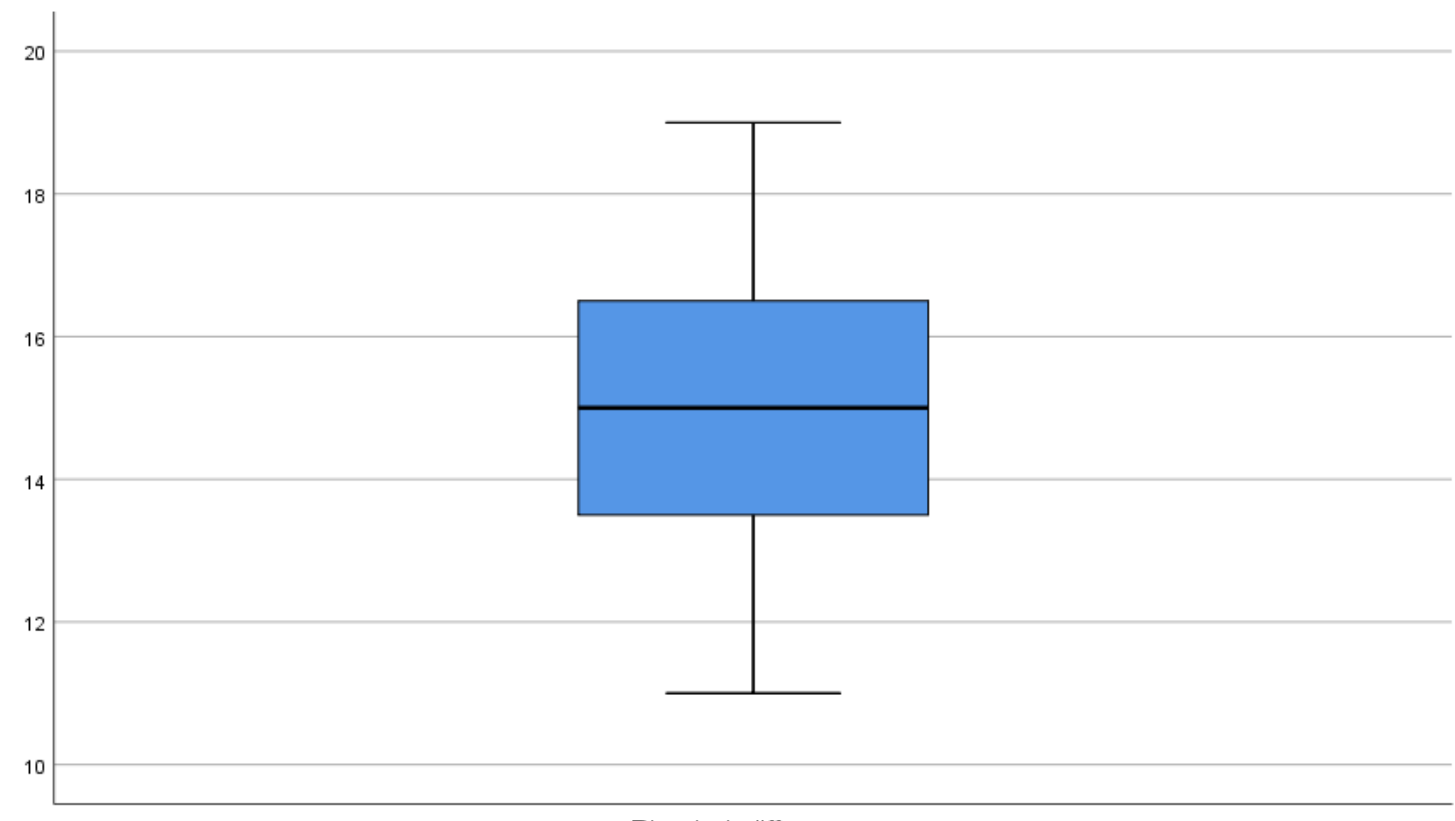

Blended differences

Figure 5: boxplot of blended course scores (post-pre) 


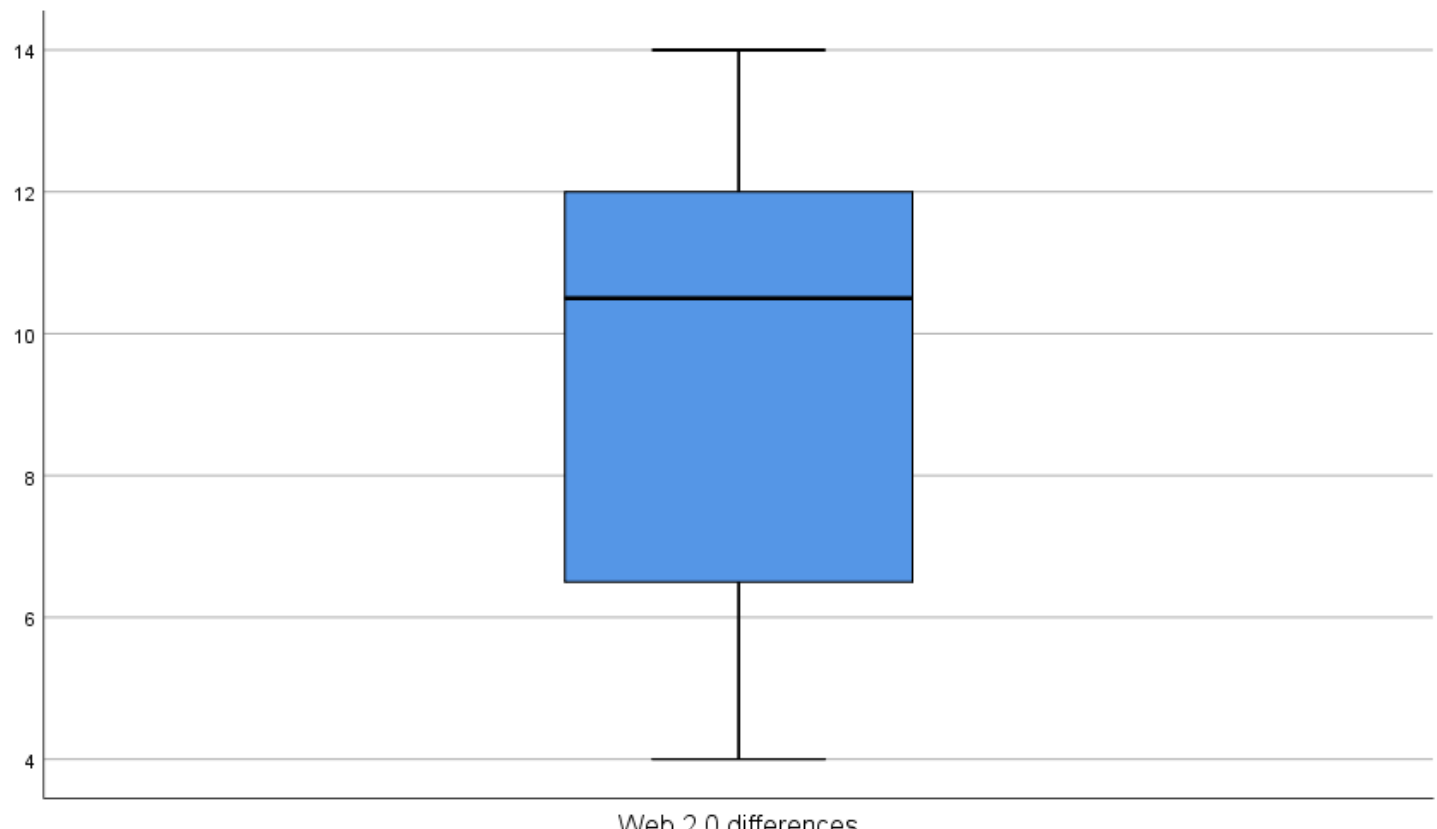

Figure 6: Boxplot of web 2.0 differences in scores (post-pre)

In summary, the paper has revealed that there is a positive impact in scores after introduction of web 2.0 and blended courses during the Covid-19 pandemic as indicated by a higher positive score in participant's experiences and reflections after the intervention. The stakeholders should therefore implement the blended course and web 2.0 tools to learners at the University.

\section{THEME 3: THE IMPACT OF LEARNING 21ST-CENTURY SKILLS IN A BLENDED COURSE USING WEB 2.0}

The Fall 2020 semester was the first time that these art students had taken a blended course using Web 2.0 tools. The blended course was a new learning method (online and F2F instruction) for the university's art education department. The students opined that the blended course was the best way to learn during the Covid-19 pandemic because it enhanced their learning through online and on-

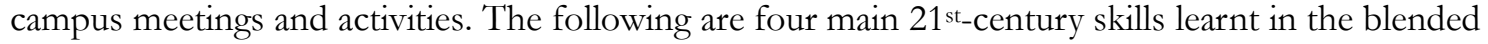
course using Web 2.0: technology literacy, creativity, decision-making and problem-solving, and collaboration and communication.

\section{Technology literacy}

The online meetings and activities helped students use Web 2.0 tools. They reported feeling more comfortable (compared with online learning) meeting the instructor on campus, since the instructor guided them to gain the necessary skills. Additionally, on-campus meetings allowed them to practice drawing and sketching. Additionally, Voki, YouTube, Pinterest were the most-used Web 2.0 tools, with $100 \%$ of students using them in the online course. Moreover, while $85.71 \%$ used WhatsApp, and $78.57 \%$ in Instagram. The following Table 10 includes the Web 2.0 tools in the blended course:

Table 10: Web 2.0 tools in the blended course

\begin{tabular}{|c|c|c|}
\hline$\#$ & Web 2.0 tools & $\mathbf{\%}$ \\
\hline 1 & Voki & $100 \%$ \\
\hline 2 & YouTube & $100 \%$ \\
\hline
\end{tabular}




\begin{tabular}{|c|c|c|}
\hline$\#$ & Web 2.0 tools & $\mathbf{\%}$ \\
\hline 3 & Pinterest & $100 \%$ \\
\hline 4 & WhatsApp & $85.71 \%$ \\
\hline 5 & Instagram & $78.57 \%$ \\
\hline
\end{tabular}

\section{Creativity}

The students could choose different characters (e.g., animals and historical figures) to include in their assignments. Thus, they were required to be creative in their projects. Pinterest and Instagram were used as inspiration sources for the art students because of their visual learning nature. The results showed that visual learning tools increased students' creativity, who created their designs using social media as a source of inspiration.

\section{Decision-making and problem-solving}

Voki tools such as Web 2.0 provided important indicators for decision-making, which was based on the students' perceptions. The students chose the topic they wanted from the various design elements and principles and presented the desired character from the chapter. They solved any problems they faced by helping each other via WhatsApp. Thus, students benefited from group work as they thought critically and solved problems by clarifying their ideas through group discussion. Students engaged in online and F2F learning activities, which increased their skills and helped them gain more knowledge of the course content.

\section{Collaboration and communication}

The students had access to different tools to communicate with each other. They liked to communicate privately by using tools such as WhatsApp. They collaborated on learning activities that helped them interact and supported their learning. Therefore, Web 2.0 tools supported learner collaboration online- the groups developed the quality of their interactions, mediated by peer critiques on their art and design sketches. Students developed a strong sense of community after the instructor had built the structure and activities in the blended course. Group assignments required students to work together via peer reviews, group work, and discussions. Students were provided with a better learning experience, which produced better learning outcomes.

\section{THEME 4: STUDENTS' EXPERIENCES AND INTERACTION USING WEB 2.0 IN BLENDED COURSE}

After the students received instruction via a blended method through the LMS (Blackboard), they participated in in-depth individual interviews. The students enjoyed using Web 2.0 during the blended course. The blended course was a new learning style with online and F2F classes in art education. Art students discussed that the blended course was the best way to learn during the Covid-19 pandemic because it enhanced their online and on-campus meetings and activities. The online meetings and activities helped students use Web 2.0 tools in Blackboard such as Voki Online Classroom, YouTube videos, Pinterest, and more. In addition, on-campus meetings helped them practice drawing and sketching. They reported that they felt more comfortable meeting the instructor on campus, which is how the instructor guided them to gain the required skills, as opposed online meetings. Voki, YouTube, and Pinterest were the top Web 2.0 tools that art students said were useful and inspiring in the artwork.

\section{Voki Classroom}

The students enjoyed creating animations in the Voki online classroom via three essential tools: Voki Create, Presenter, and Hangouts. Figure 7 shows the Voki website (www.voki.com). 


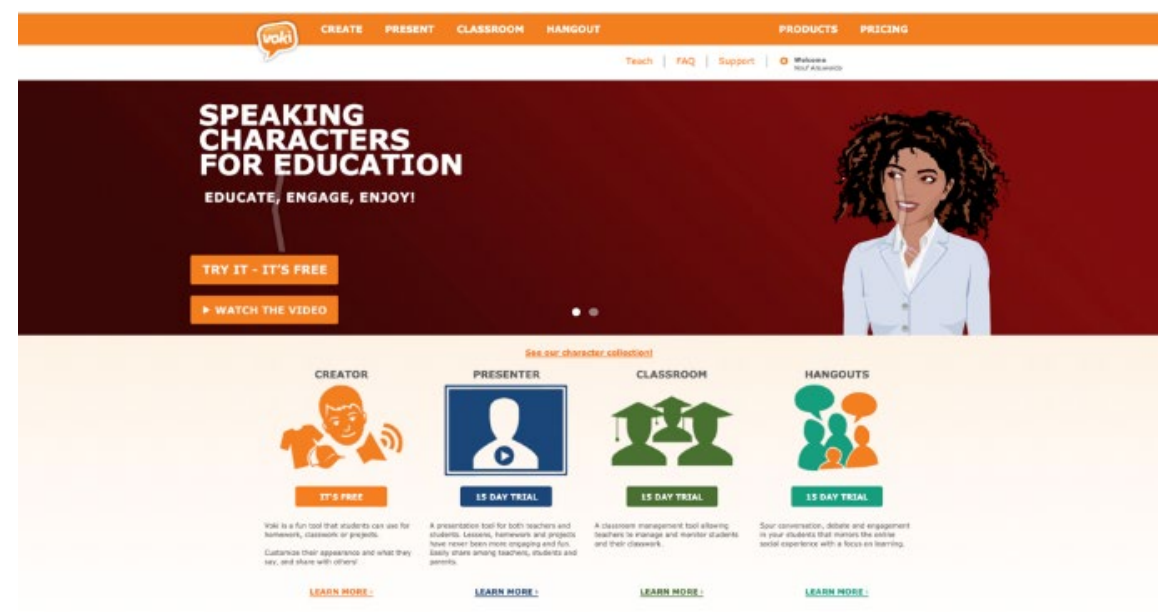

Figure 7: Voki website

\section{Voki Create}

Students had a positive experience learning with the Voki Create avatar animation tools, which allowed them to create a customized talking avatar (Figure 8). Students mentioned using different characters (e.g., anime characters, animals, and historical figures) in their assignments. Students also noted that Voki Create could add accessories, backgrounds, and voices from text or recorded by a microphone to their avatars. In the individual student interviews, participants reported positive experiences taking a blended course with Web 2.0 tools, such as the Voki animation tool, and sharing their work on social media. Students also expressed a desire for all professors to include Voki in their art and design programs. For instance, one student said, "It's a new and fun technology tool to create an animated character. It looks like Snapchat images."

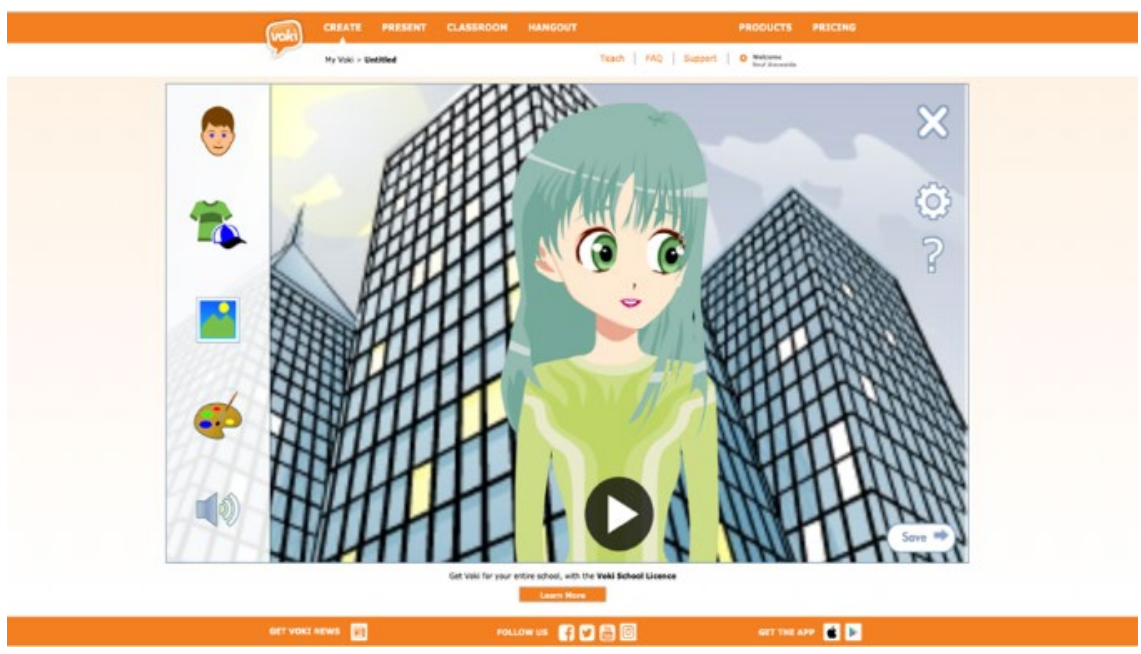

Figure 8: Voki Create tool

\section{Voki Presenter}

Figure 9 shows the Voki Presenter tool. Students explained that this tool was accessible, efficient, and easy to use when creating their animated characters. Students further noted that Voki Presenter allowed them to create their avatar, encouraging their peers to pay more attention to their presentation. They could also expand their presentation by adding slides, top characters, text, images, YouTube or 
Vimeo videos, backgrounds, and shapes. When students used Voki in the online classroom, they preferred to use their smartphones to share links faster with the instructor and their classmates via WhatsApp. For instance, one student said: "I like Voki Presenter because it [helps me] acquire teamwork experience. Also, I have more interactions with my classmates." All participants preferred using social media via smartphone apps and agreed that Voki captured their attention and kept them engaged in the class. Students liked the animated characters because they could create, play with, edit, and delete their work before submitting the assignment. The tools engaged students' learning and design innovation, and they felt connected with each other and the professor. However, some students argued that the application was often slow and needed improvement.

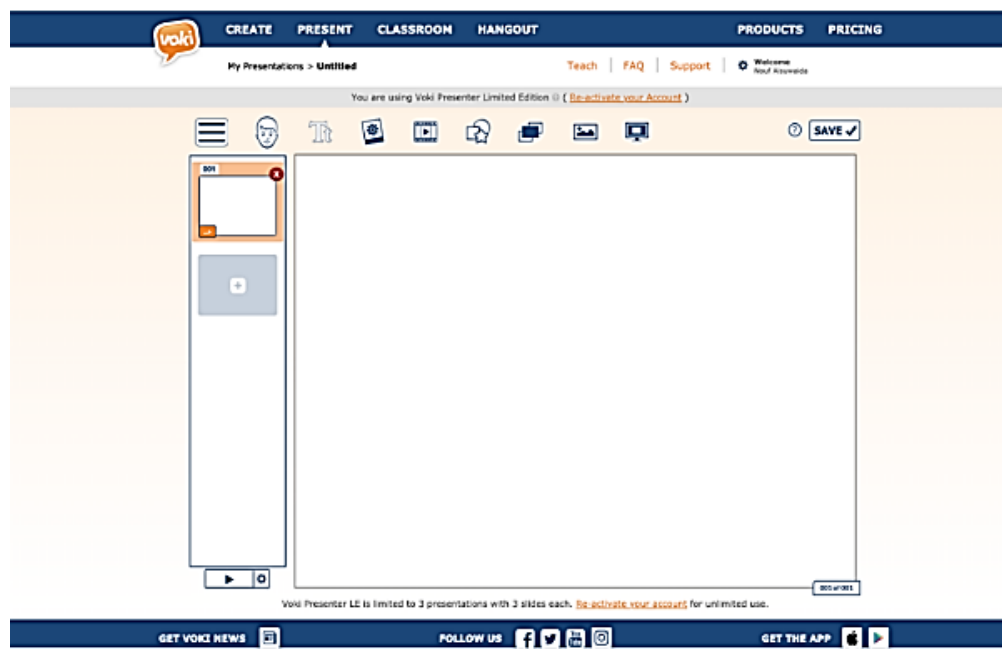

Figure 9: Voki Presenter tool

\section{Voki Hangouts}

Students used Voki Hangouts to share their experiences with their classmates and instructor. Each Hangout contained teacher-defined topics on which students could comment. Students received an invitation from the instructor and could reply to one other. Example comments from the students included, "It is a learning community tool designed to encourage intelligent student conversations using Voki speaking avatars. I learn English art vocabulary when I use Voki." All students paid attention to the colorful and interactive Voki website and hoped that the art education department would use similar technologies in the art and design curriculum. Figure 10 shows the layout of the Voki Hangouts tool.
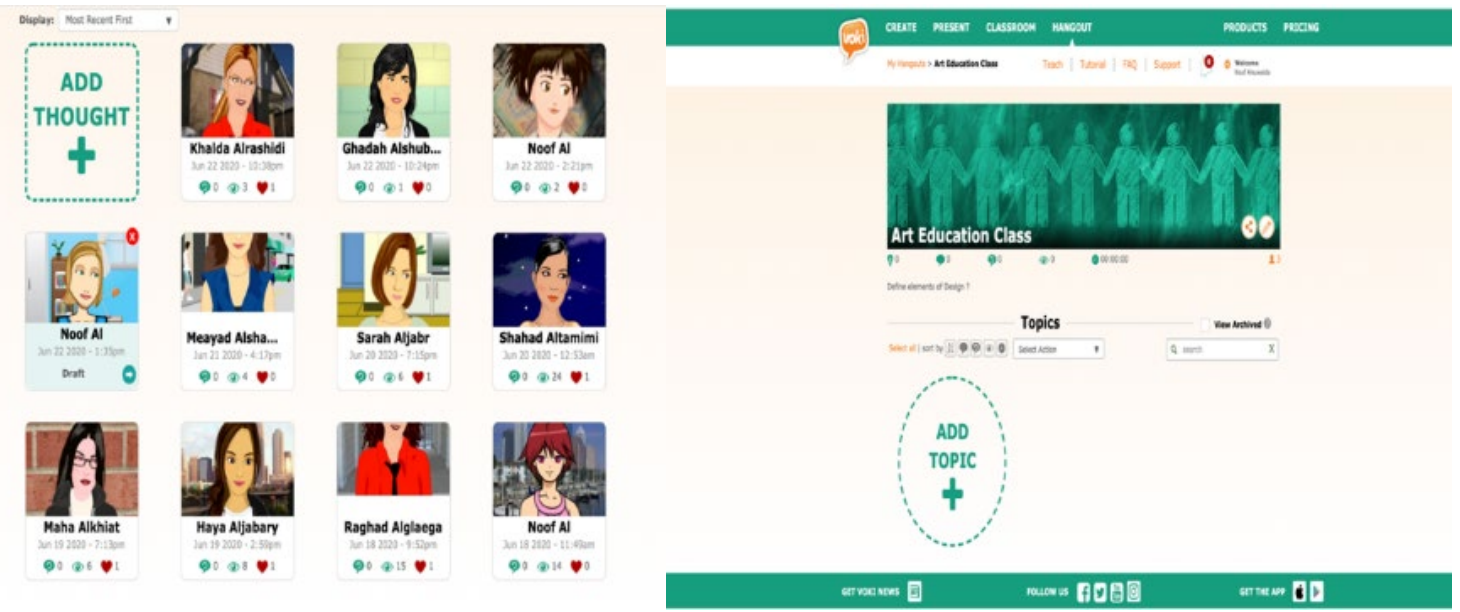

Figure 10: Voki Hangouts tool 


\section{You'Tube}

The YouTube video platform has become one of the most popular online applications that all students engage with in distance education. YouTube helps teachers perfect teaching methods and develop curricula in their courses (Neumann \& Herodotou, 2020). In this study, before the F2F class in the blended course, the instructor gave students YouTube tools, such as videos, for each model. Students discussed and practiced using the link between the pre-online and F2F sessions during the semester. YouTube helped students self-learn by watching videos along with the design, step by step. Example comments from the students included, "YouTube is the best tools for self-learning. I am always searching videos to figure out what I did not understand in the classroom." Students mentioned that the instructor posted videos before on-campus meetings to explain and discuss art processes in-depth. Also, it supported the researcher in designing effective teaching methods and developing a curriculum in the course (Figure 11).

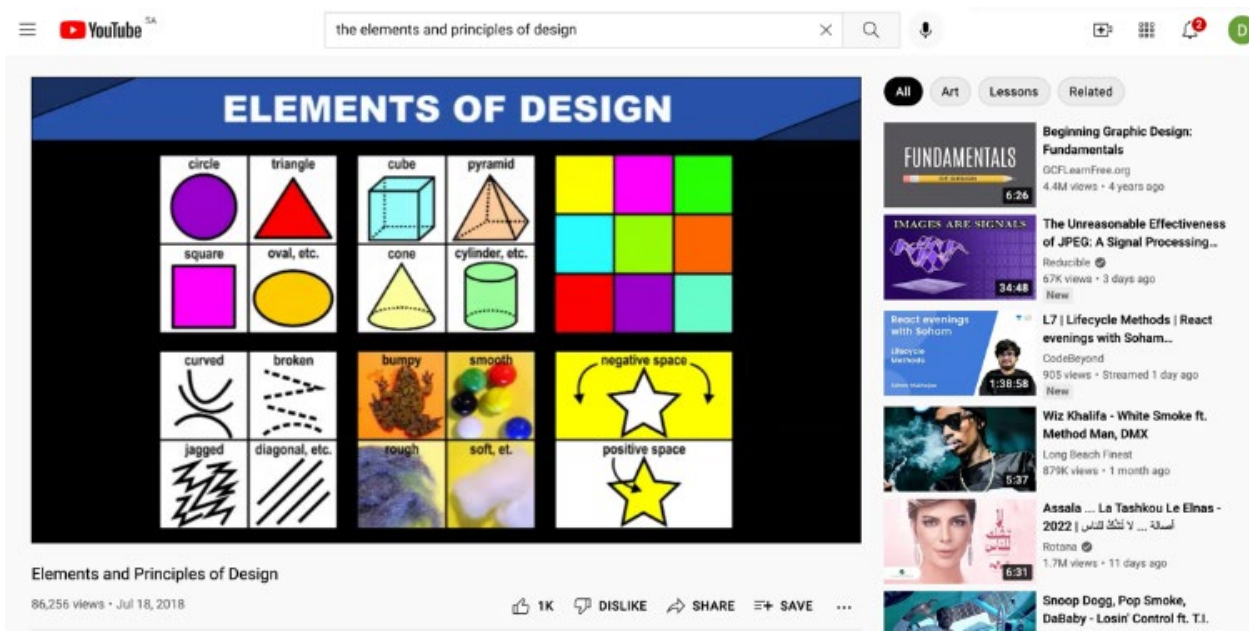

Figure 11: YouTube video in art and design

\section{Pinterest}

Pinterest is an image-sharing social service that has attracted a great deal of attention recently and has become one of the most popular social networks (Feng et al., 2013). Art is one of the most popular and content-generating categories on this platform. It is a photo-sharing website that allows users to create and manage photo collections based on themes. The researcher gave students assignments using Pinterest and searching images by art subjects. For example, the researcher created "Pinboards" for each module in the blended course (Figure 12), like the design elements in the module (2). Students enjoyed sharing images and creating new ideas for their sketches from Pinterest. Example comments from the students included, "It is free, flexible, provides quick access, and helps me to generate diverse ideas." Other students mentioned building an art "Pinboard" comprising unmissable ideas. It also has a tidy set of virtual boards instead of a mammoth file folder with ripped magazine pages. Interacting virtually and looking at unique content can be a great source of inspiration for students through visual stimulation using Pinterest. Example comments from the students included, "It is fun! Also, it is a source of inspiration and innovation for our design."

The researcher's role was to provide students a Pinterest tool to help them understand the subject, achieve the stated learning objectives about art and design step by step, and show videos explaining the method of drawing and coloring in art and design. More specifically, it presented students with a set of digital files for "Pinboards," or just user boards, known as "Pinners," saved bookmarks of web content, known as "Pins," to "Boards." The teacher shared "Pins" among students to visualize an image that summarizes what each Pin represents. The site took students to the main web page that 
hosts the image and related content by clicking on the Pin. The researcher's goal was to allow students to comment and link to the image source when the Pin was created. Thus, other community members could "Add," "Like," or "Re-pin" comments. The researcher also wanted students to connect with artists, designers, photographers, and other creative professionals worldwide through Pinterest. For instance, one student said, "It is social because classmates or friends can see what you are up to, comment, and share photos."

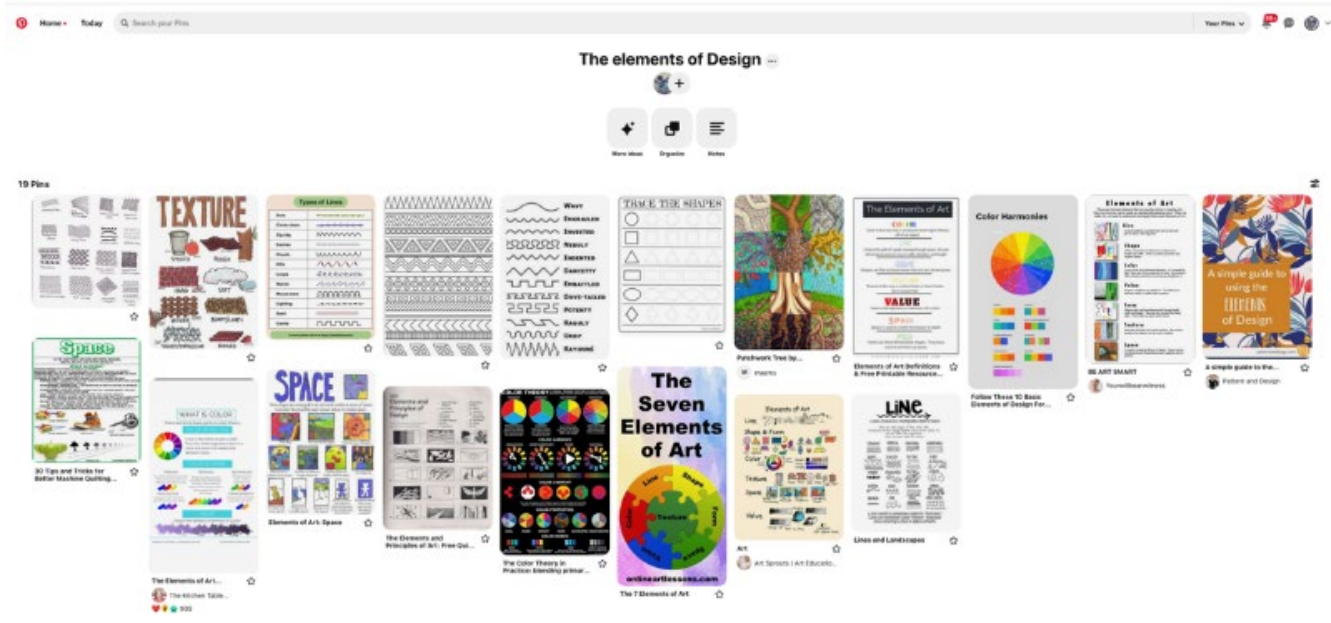

Figure 12: The elements of design in Pinterest (module 2)

\section{DISCUSSION}

The result is presented in four themes according to the one research question: "How does the instructor design and evaluate a blended (hybrid) course designed to use Web 2.0 tools in a fine arts program?" During the study, the researcher changed the course instruction format from $100 \%$ traditional classroom teaching to a blended course, which seemed to be an effective learning design for both instructor and students during the Covid-19 pandemic. Blended or flipped courses can provide a new pedagogical approach to upgrade Saudi Arabian universities' guidelines on delivering their programs. From the students' perspective, the QMHER was useful, as it allowed them to know how to meet the course requirements and improve their grades.

The four themes identified from analyzing the data were: 1) designing a blended learning course with the QMHER in an Art Education program, 2) students' evaluation of the blended course using Web $2.0,3)$ the impact of learning $21^{\text {st }}$ century skills in a blended course using Web 2.0, and 4) students' experiences and interaction using Web 2.0 in blended course.

The first theme derived from an analysis of the 8 Standers from the QMHER was to design a blended course. The researcher used technology to improve access, increase efficiency, enhance presence, deepen engagement and satisfaction, and improve learning outcomes. The researcher took advantage of technological benefits for the blended course. A noteworthy point about this research is that varied technological resources were incorporated in the course. First, Blackboard, a learning management system (LMS), was included as a part of the technological strategy. The LMS is a hybrid tool that facilitates the evaluation of students' work, such as tests, assignments, surveys, and discussion boards. It allows automatic grading with instant feedback reporting and analysis (Aljawarneh, 2020). Thus, Dilmaç (2020) found that students argued that laboratory studies could not be conducted exclusively through online courses; they need an in-person laboratory for this type of learning and cannot perform their experiments at home; thus, some aspects of art education can only be carried out in a workshop environment. In other words, art and design lessons cannot be taught entirely through distance education because they are application-oriented, and exclusively-online lessons can reduce students' creativity and self-confidence (Adedoyin \& Soykan, 2020). The second technology 
used during the blended course, Web 2.0 tools, offers students a better way to interact with each other and with the content. Web 2.0 tools_-Voki, YouTube, Pinterest, Instagram, and WhatsAppsupported the learning objectives and the criteria and standards for quality online education, such as the QMHER. The researcher chose fun and novel tools for art students and helped students achieve their learning objectives in the blended course.

The second theme that emerged from the pre-test and post-test one focus group questionnaire was that none of the participants had a working knowledge of either blended courses or Voki. However, the results showed that all students had experience using Web 2.0 tools to enhance their learning. These tools were easy to learn on a smartphone because they had prior knowledge of using mobile apps. Students also used other devices, such as tablets and laptops.

Through a blended course, the third theme highlighted an improvement in students' learning of 21 stcentury skills (including technology literacy, creativity, decision-making, problem-solving, and collaboration and communication). Students used Web 2.0 tools to enable their learning and social interactions, which helped the participants when the researcher added activities and assignments in the online classroom. The findings also emphasized the benefits of using Web 2.0 tools to develop new teaching approaches to motivate students. The study's results showed that, Web 2.0 tools were effective for students' academic achievement in blended courses. There are various advantages to using Web 2.0 tools that can help higher education students succeed in online or blended courses and achieve success in their future careers. Lai and Bower (2019) expressed that learning outcomes and students' behavior are a few of the evaluation criteria for online courses. In the present study, students' behavior changed positively during the blended course, as the Web 2.0 tools made them feel happy and excited and helped them enjoy more while learning online.

The fourth theme was supported by a descriptive analysis of the in-depth individual interviews. Findings showed that, as a new technology tool, the introduction of Voki to the class helped the participants engage in learning. The results highlighted that students felt comfortable learning through the blended course using Voki. Additionally, they became self-learners responsible for their academic success and learned to complete their work individually or in teams. Voki offers three unique tools on its website: Create, Present, and Hangout. Students used the Create tool to introduce themselves in Module (1) of the blended course. When students used Voki tools, they had two options to share their animated videos. First, they could embed a code from the Voki website to share the videos with the group and instructor via social media, such as Facebook, Twitter, blogs, or emails. Students also shared their Voki Creator animation links with their instructor and classmates in WhatsApp groups. Even though a few students were not proficient in English, they reported that the language used was easy to understand; further, the website also supports Arabic. The participants also noted that the professor allowed them to use both languages.

After using Voki, students exhibited optimism, were engaged, and created animations in the online classroom; student learning is improved by an ebullient learning environment, which also enhances students' motivation. In addition, shy students seemed to be more confident when they were learning via this tool because they could record different voices. Students liked Voki Present because it helped them acquire teamwork experience and more interactions with their classmates. In Voki Hangouts, students felt that everyone had equal learning opportunities as they all shared their thoughts and posted their animations on the same topic.

YouTube was another Web tool that supported students' self-learning through videos with a step-bystep design presented before the F2F meeting in the blended course. Pinterest was also conceived as an inspirational tool for art and design students. In addition, students used WhatsApp as a communication tool to share their opinions and images in a private group. In contrast, students mentioned some downsides, such as device- and network-related problems. The Voki mobile app sometimes did not function correctly on their smartphones; consequently, the students preferred to use the desktop version of the Voki online classroom. Furthermore, the focus group discussions highlighted issues 
related to technology use in art and design, such as the extraction of outdated information, loneliness, and a lack of strong relationships between students.

\section{CONCLUSIONS}

This study's main focus was to design and evaluate the impact of using a blended course and Web 2.0 tools into the "Design Fundamentals and Elements" course of a fine arts bachelor's program at a Saudi Arabian university in Fall 2020. The study also examined how students used Web 2.0 tools to improve their learning in the design of a blended (hybrid) course following the Quality Matters TM Higher Education Rubric (QMHER). The flipped classroom model provided a new pedagogical approach to design blended learning with the QMHER in art education. Blended courses are viable education modalities during the global Covid-19 pandemic, necessitating social distancing. In this context, the study was answering the following question: "How does the instructor design and evaluate a blended (hybrid) course intended to use Web 2.0 tools in a fine arts program?"

The study revealed four main themes: 1) designing a blended learning course with the QMHER in an Art Education program, 2) students' evaluation of the blended course using Web 2.0, 3) the impact of learning $21^{\text {st }}$ century skills in a blended course using Web 2.0, and 4) students' experiences and interaction using Web 2.0 in blended course.

The QMHER was valuable for students' understanding of the course requirements and to improve their grades. Moreover, many Web 2.0 tools were helpful in teaching and learning art and design concepts via a blended course to improve students' skills. The findings highlight how students' 21st-century skills increased by using a blended course using Voki.

This study had some limitations. First, its methodological approach involved using a teaching method that was new to both the instructor and the students. As it was their first time using Voki in a blended art and design course, students needed to understand the Voki classroom. Second, when gathering feedback from the participants, the researcher realized that some students ignored the use of technology and did not respond to email requests for feedback. This problem resulted in rescheduling the interview times and dates using online meeting platforms such as Google Hangouts. Based on the research findings, the following recommendations are made for higher education institutions that provide art and design curricula and degree programs:

- The QMHER should be applied to both online and blended higher education courses in Saudi Arabia and internationally.

- Art and design teaching and learning should be transformed through Web 2.0 tools, allowing students to explore their design capabilities in the fine arts, art education, interior design, fashion design, and graphic design fields.

Blended courses should be integrated with the QMHER and Web 2.0 tools into art and design curricula.

\section{ACKNOWLEDGEMENTS}

The author extends her appreciation to the Deanship of Scientific Research at the University of Ha'il in Saudi Arabia for funding this research work: project number (BA-2011).

\section{REFERENCES}

Adedoyin, O. B., \& Soykan, E. (2020). COVID-19 pandemic and online learning: The challenges and opportunities. Interactive Learning Environments, Online first. https://doi.org/10.1080/10494820.2020.1813180

Alghamdi, A. A. (2021). Impact of the COVID-19 pandemic on the social and educational aspects of Saudi university students' lives. PloS One, 16(4), e0250026. https://doi.org/10.1371/journal.pone.0250026 
A Blended Art Education Course and Web 2.0 Tools in Saudi Arabia

Al-Nofaie, H. (2020). Saudi university students' perceptions towards virtual education during COVID-19 pandemic: A case study of language learning via Blackboard. Arab World English Journal, 11(3), 4-20. https://doi.org/10.24093/awej/vol11no3.1

Aljawarneh, S. A. (2020). Reviewing and exploring innovative ubiquitous learning tools in higher education. Journal of Computing in Higher Education, 32(1), 57-73. https://doi.org/10.1007/s12528-019-09207-0

Andrade, M., \& Coutinho, C. (2016, November). Implementing flipped classroom in blended learning environments: A proposal based on the cognitive flexibility theory. In Proceedings of E-learn: World Conference on Elearning in Corporate, Government, Healthcare, and Higher Education (pp. 1115-1125). Washington, DC: Association for the Advancement of Computing in Education (AACE). https://repositorium.sdum.uminho.pt/bitstream/1822/43379/1/proceeding 174050.pdf

Baglama, B., Yucesoy, Y., \& Yikmis, A. (2018). Using animation as a means of enhancing learning of individuals with special needs. TEM Journal, 7(3), 670-677. https://www.ceeol.com/search/article-detail $P i d=691066$

Beatty, G., Biggs, B., Leckman, T., \& Raymond, S. (2020, August). Best practices in computer classroom layout. In Proceedings of the ACM SIGGRAPH 2020 Educator's Forum (pp. 1-2). ACM. https://doi.org/10.1145/3388530.3408880

Bieraugel, M., \& Neill, S. (2017). Ascending Bloom's pyramid: Fostering student creativity and innovation in academic library spaces. College \& Research Libraries, 78(1), 35-52. https://doi.org/10.5860/crl.78.1.35

Bishnoi, M. M. (2020). Flipped classroom and digitization: An inductive study on the learning framework for $21^{\text {st }}$ century skill acquisition. The Journal for Educators, Teachers and Trainers, 11(1), 30-45. https://dialnet.unirioja.es/descarga/articulo/7705794.pdf

Burwash, S. C., Snover, R., \& Krueger, R. (2016). Up Bloom's pyramid with slices of Fink's pie: Mapping an occupational therapy curriculum. The Open Journal of Occupational Therapy, 4(4), Article 7. https://doi.org/10.15453/2168-6408.1235

Cicconi, M. (2014). Vygotsky meets technology: A reinvention of collaboration in the early childhood mathematics classroom. Early Childhood Education Journal, 42(1), 57-65. https://doi.org/10.1007/s10643-013$\underline{0582-9}$

Cunningham, J. (2013). Voki in the classroom: Four activities. Education World. https://www.educationworld.com/a lesson/using-voki-in-the-classroom.shtml

Dilmaç, S. (2020). Students' opinions about the distance education to art and design courses in the pandemic process. World Journal of Education, 10(3), 113-126. https://doi.org/10.5430/wje.v10n3p113

Frick, T. W. (1991). Restructuring education through technology: 30 years later. Phi Delta Kappa (PDK) Educational Foundation. https:// files.eric.ed.gov/fulltext/ED350995.pdf

Futch, L. S., DeNoyelles, A., Thompson, K., \& Howard, W. (2016). "Comfort" as a critical success factor in blended learning courses. Online Learning, 20(3), 140-158. https://doi.org/10.24059/olj.v20i3.978

Feng, Z., Cong, F., Chen, K., \& Yu, Y. (2013, November). An empirical study of user behaviors on Pinterest social network. In Proceedings of the IEEE/WIC/ACM International Joint Conferences on Web Intelligence (WI) and Intelligent Agent Technologies (LAT) (Vol. 1, pp. 402-409). Atlanta, GA: IEEE. https://doi.org/10.1109/WI-IAT.2013.57

Graham, C. R. (2006). Blended learning systems. In C. J. Bonk, \& C. R. Graham (Eds.), The bandbook of blended learning: global perspectives, local designs (pp. 3-21). Pfeiffer Publishing. http://kenanaonline.com/files/0036/36463/BLENDED\%20LEARNING\%20SYSTEMS.pdf

Gregory, R. L., Rockinson-Szapkiw, A. J., \& Cook, V. S. (2020). Community college faculty perceptions of the Quality Matters TM Rubric. Online Learning, 24(2), 128-141. https://doi.org/10.24059/olj.v24i2.2052

Hamdan, A. J. (2019). The use of animation movie as a teaching media to improve students' speaking skill at seventh grade of Mts Al-ittihad Poncokusumo Malang. Jurnal Penelitian, Pendidikan, dan Pembelajaran, 13(1), 48-51. http://www.riset.unisma.ac.id/index.php/jp3/article/viewFile/2938/2678 
Jintapitak, M. (2018, February). Use of animation characters to motivate students in a higher education class. Proceedings of the 2018 International Conference on Digital Arts, Media and Technology (ICDAMT) (pp. 280-284). Phayao, Thailand: IEEE. https://doi.org/10.1109/ICDAMT.2018.8376540

Kaya, H. (2015). Blending technology with constructivism: Implications for an ELT classroom. Teaching English with Technology, 15(1), 3-13. https:// files.eric.ed.gov/fulltext/EJ1140571.pdf

Keengwe, J., \& Agamba, J. J. (2015). Models for improving and optimizing online and blended learning in higher education. IGI Global. https://doi.org/10.4018/978-1-4666-6280-3

Lai, J. W., \& Bower, M. (2019). How is the use of technology in education evaluated? A systematic review. Computers \& Education, 133, 27-42. https://doi.org/10.1016/j.compedu.2019.01.010

Lalima, \& Dangwal, K. L. (2017). Blended learning: An innovative approach. Universal Journal of Educational Research, 5(1), 129-136. https://doi.org/10.13189/ujer.2017.050116

Manning, S., \& Johnson, K. E. (2011). The technology tool belt for teaching. John Wiley \& Sons.

Manty, M., Yunus, M. M., Badusah, J., \& Shah, P. M. (2017, January). Using Voki to enhance speaking skills. In Proceedings of the Seminar on Transdisciplinary Education (STEd2017) (pp. 668-672). Bangi, Selangor: National University of Malaysia (UKM). https://sted18.files.wordpress.com/2016/12/4-11-michelle-manty-melormd-yunus-jamaludin-hj-badusah-parilah-m-shah.pdf

Mayer, R. E., \& Moreno, R. (2002). Animation as an aid to multimedia learning. Educational Psychology Review, 14(1), 87-99. https://doi.org/10.1023/A:1013184611077

Minnesota State University Moorhead (2014, April 18). The Instructor's guide to course development \& facilitation for online, bybrid, \& technology-enhanced courses. https://academics.nsuok.edu/Portals/53/Instructors $\% 20$ Guide $\% 20$ To $\% 20$ Online $\% 20$ Course $\% 20$ Development $\% 20$ And $\% 20$ Facilitation.pdf

Moorhouse, B. L., \& Kohnke, L. (2021). Thriving or surviving emergency remote teaching necessitated by COVID-19: University teachers' perspectives. The Asia-Pacific Education Researcher, 30(3), 279-287. https://doi.org/10.1007/s40299-021-00567-9

Neumann, M. M., \& Herodotou, C. (2020). Evaluating YouTube videos for young children. Education and Information Technologies, 25(5), 4459-4475. https://doi.org/10.1007/s10639-020-10183-7

O'Flaherty, J., \& Phillips, C. (2015). The use of flipped classrooms in higher education: A scoping review. The Internet and Higher Education, 25, 85-95. https://doi.org/10.1016/j.iheduc.2015.02.002

Paik, E. S., \& Schraw, G. (2013). Learning with animation and illusions of understanding. Journal of Educational Psychology, 105(2), 278-289. https://doi.org/10.1037/a0030281

Quality Matters (n.d.). Why QM? https://www.qualitymatters.org/why-quality-matters

Raiyn, J. (2016). The role of visual learning in improving students' high-order thinking skills. Journal of Education and Practice, 7(24), 115-121. https:// files.eric.ed.gov/fulltext/EJ1112894.pdf

Reuben, R. (2008). The use of social media in higher education for marketing and communications: A guide for professionals in higher education. MBA Dissertation. Albany, New York: State University of New York (SUNY). https://www.semanticscholar.org/paper/The-Use-of-Social-Media-in-Higher-Education-for-and-Reuben/a115cbc56842941bd4f04a363fd69e42c6ea857d

Rice, M., \& Oritz, K. (2020). Perceptions of accessibility in online course materials: A survey of teachers from six virtual schools. Journal of Online Learning Research, 6(3), 245-264. https://www.learntechlib.org/primary/p/217628/paper 217628.pdf

Riley, H. (2017). Drawing as driver of creativity: Nurturing an intelligence of seeing in art students. The International Journal of Art \& Design Education, 36(3), 273-280. https://doi.org/10.1111/jade.12157

Rodger, S. H., Hayes, J., Lezin, G., Qin, H., Nelson, D., Tucker, R., Lopez, M., Cooper, S., Dann, W., \& Slater, D. (2009). Engaging middle school teachers and students with Alice in a diverse set of subjects. $A C M$ SIGCSE Bulletin, 41(1), 271-275. https://doi.org/10.1145/1508865.1508967 
A Blended Art Education Course and Web 2.0 Tools in Saudi Arabia

Saliba, G., Rankine, L., Cortez, H. (2013). Fundamentals of blended learning. University of Western Sydney, Blended Learning Team, Learning and Teaching Unit. https://www.westernsydney.edu.au/ data/assets/pdf file/0004/467095/Fundamentals of Blended Learning.pdf

Solomon, G., \& Schrum, L. (2014). Web 2.0: How-to for educators. International Society for Technology in Education. https://dl.acm.org/doi/book/10.5555/2685776

Thompson, K., \& Lodge, J. M. (2020). 2020 vision: What happens next in education technology research in Australia. Australasian Journal of Educational Technology, 36(4), 1-8. https://doi.org/10.14742/ajet.6593

Wamboldt, V. (2021). Elements and principles of design. A great tool to learn about design: Designing principle guide. Independently Published.

Wallace, L., \& Young, J. (2010). Implementing blended learning: Policy implications for universities. Online Journal of Distance Learning Administration, 13(4), 7. http://citeseerx.ist.psu.edu/viewdoc/download?doi $=10.1 \cdot 1 \cdot 1003.8732 \& \mathrm{rep}=$ rep1\&type $=$ pdf

Xiao, L. (2013). Animation trends in education. International Journal of Information and Education Technology, 3(3), 286-289. http://ijiet.org/papers/282-JR112.pdf

Yeşilbağ, S., \& Korkmaz, Ö. (2021). The effect of Voki application on students' academic achievements and attitudes towards English course. Education and Information Technologies, 26(1), 465-487. https://doi.org/10.1007/s10639-020-10264-7

Zaidi, N. B., Hwang, C., Scott, S., Stallard, S., Purkiss, J., \& Hortsch, M. (2017). Climbing Bloom's taxonomy pyramid: Lessons from a graduate histology course. Anatomical Sciences Education, 10(5), 456-464. https://doi.org/10.1002/ase.1685

\section{AUTHOR}

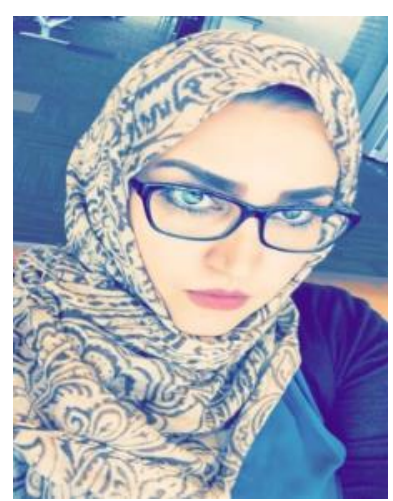

Nouf Alsuwaida is an assistant professor at the University of Ha'il in Saudi Arabia. Her doctoral studies focus on Educational Learning Technologies in the field of Art and Design at New Mexico State University in the United States. Nouf's teaching experience includes art and design, graphic design, fashion design, traditional fashion architecture, and textiles. Her research interests are in women's education issues, women's traditional clothing, teaching and learning in art and design, curriculum \& instruction, e-learning, and QM educational design models, and technology theories in pedagogy. If you want to contact Alsuwaida, please email her at nalsuwaida@hotmail.com or n.alsuwaida@uoh.edu.sa 